Institut für Ost- und

Südosteuropaforschung

Institute for East and

Southeast European Studies

Arbeitsbereich Ökonomie

IOS Working Papers

No. 324 November 2012

\title{
The Euro Plus Pact: Competitiveness and External Capital Flows in the EU Countries
}

Hubert Gabrisch*, and Karsten Staehr ${ }^{* *}$

\footnotetext{
** Halle Institute for Economic Research (IWH), Germany.

** Corresponding author: TSEBA, Tallinn University of Technology, Akadeemia tee 3-486, 12618 Tallinn, Estonia. E-mail: karsten.staehr@tseba.ttu.ee. Tel.: +372 6204062. Fax: +3726204051.
} 
Institut für Ost- und

Südosteuropaforschung

Institute for East and

Southeast European Studies

Landshuter Straße 4

D-93047 Regensburg

Telefon: (0941) 94354-10

Telefax: (0941) 94354-27

E-Mail: info@ios-regensburg.de Internet: www.ios-regensburg.de 


\section{Contents}

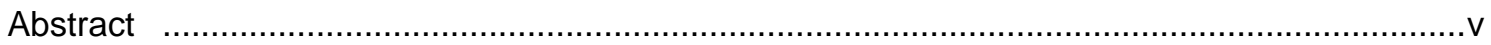

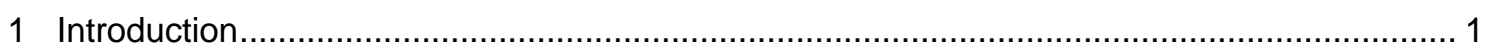

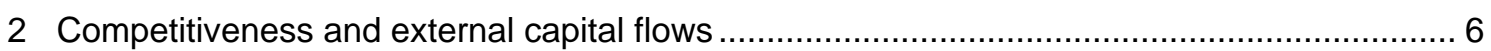

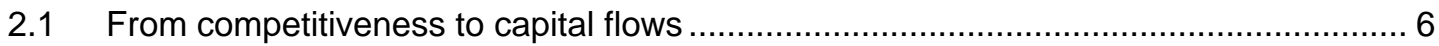

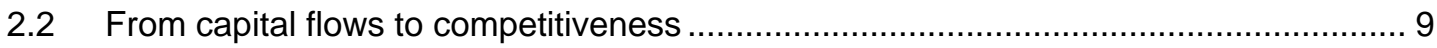

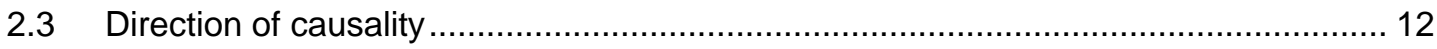

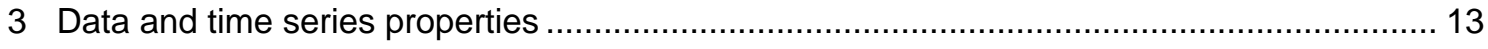

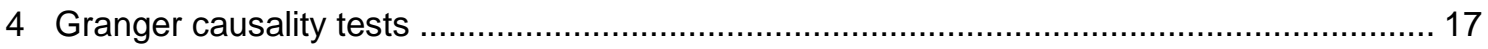

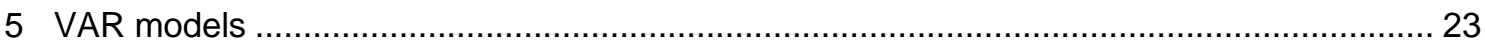

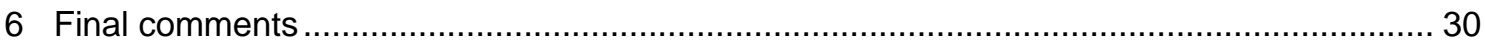

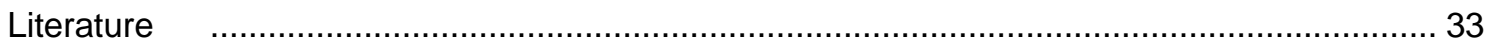

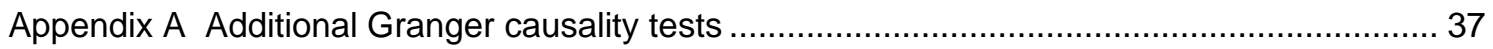

Appendix B Impulse responses for VAR model with CEE countries .................................... 39

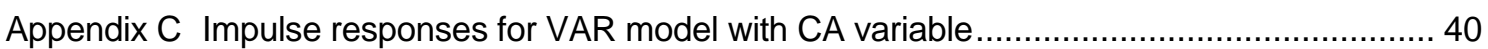

\section{List of Tables}

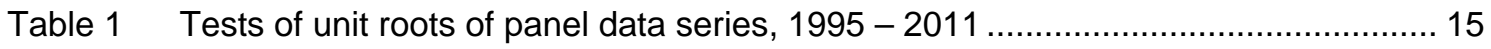

Table 2 Panel data Granger causality tests. Dependent variable DCA ......................... 18

Table 3 Panel data Granger causality tests. Dependent variable GRULC .........................20

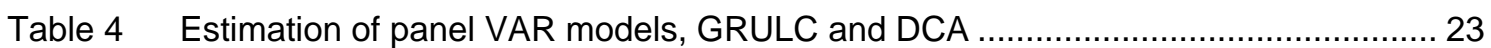

Table A1 Panel data Granger causality tests. Dependent variable CA............................... 37

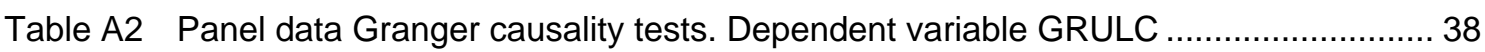




\section{List of Figures}

Figure 1 Crossplots between the change in the relative unit labour cost and the current account balance, and changes in the current account balance

Figure 2 Response of DCA and GRULC to innovations in GRULC and DCA, non-factorised innovations, $27 \mathrm{EU}$ countries

Figure 3 Response of DCA and GRULC to innovations in GRULC and DCA, different identification schemes, $27 \mathrm{EU}$ countries

Figure B1 Response of DCA and GRULC to innovations in GRULC and DCA, different identification schemes, CEE countries

Figure C1 Response of CA and GRULC to innovations in GRULC and CA, different identification schemes, all countries 


\begin{abstract}
The Euro Plus Pact was approved by 23 EU countries in March 2011. The Pact stipulates a range of quantitative targets meant to strengthen competitiveness and convergence with the ultimate aim of preventing unsustainable financial imbalances from accumulating. This paper uses Granger causality tests and VAR models to assess the direction of causality between changes in the relative unit labour cost and the current account balance. The sample consists of the $27 \mathrm{EU}$ countries for the period 1995-2011. The main finding is that changes in the current account balance affects changes in relative unit labour costs, while there is no discernable effect in the opposite direction. This suggests that the divergence in the unit labour cost between the core countries in Northern Europe and the countries in Southern and Central and Eastern Europe prior to the global financial crisis was partly the result of capital flows from the European core to the periphery. The results call into question the ability of the Euro Plus Pact to avert financial imbalances related to increasing current account deficits in future.
\end{abstract}

JEL-Classification: E61, F36, F41

Keywords: European integration, policy coordination, unit labour costs, current account imbalances, economic crisis

The authors would like to thank participants at presentations at Mendel University, Eesti Pank, the ECEE4 conference in Tallinn, IOS in Regensburg and the WWWforEurope workshop on "European governance and the problems of peripheral countries" in Vienna for useful comments. All remaining errors are the responsibility of the authors. Staehr acknowledges support from Estonian Base Financing grant no. B617A and Estonian Target Financing grant no. SF0140059s12. The views expressed are those of the authors and not necessarily those of the institutions to which they are affiliated. 



\section{Introduction}

The global financial crisis had pronounced effects on all European economies from as early as 2008, leading to substantial output losses in most EU countries. In a short time the crisis metamorphosed into a debt crisis as lending dried up and growth prospects deteriorated. Governments in the geographical periphery had to seek assistance from the IMF, the European Commission and other official lenders. Given this background, European economic governance structures came under scrutiny and a host of reforms were adopted with the aim of reducing the probability of future crises occurring in individual countries. Among the reforms adopted were Europe 2020, a new growth strategy; the Euro Plus Pact, in part to ensure financial stability; and the Fiscal Compact, setting new fiscal targets. ${ }^{1}$ This paper discusses the Euro Plus Pact and seeks to assess its likely effectiveness.

The preparation of the Euro Plus Pact can be traced back to the autumn of 2010 when the diverging economic fortunes of European countries in the euro area became very noticeable (The Economist 2011, Groll \& van Roye 2011). Consultations between the German and French governments led to the Competitiveness Pact, which was unveiled in February 2011. After some alterations had been made and a new name given, the Euro Plus Pact was adopted at a European Council meeting on 25 March 2011 (European Council 2011). ${ }^{2}$ All the euro area countries and the other EU countries except the Czech Republic, Hungary, Sweden and the United Kingdom signed up to the pact.

The goal of the Euro Plus Pact is to foster competitiveness and convergence among the participating countries with the aim of avoiding the build-up of financial and economic imbalances. The Pact stipulates a number of policy measures which should be applied for these goals to be reached, including a review of wage setting arrangements, indexation schemes, public sector wages and structural reforms to enhance productivity. There are also measures to foster employment, enhance the sustainability of public finances and

\footnotetext{
1 The webpage http://www.ecb.int/mopo/eaec/ecopolicy/html/index.en.html describes the many reforms and provides links to source material.

2 The word plus in the Euro Plus Pact is intended to have two meanings. First, it imposed new governance structures in addition to those in place at the time of its inception. Second, while it is compulsory for the euro area countries, other EU countries are also able to join the pact.
} 
improve financial stability. The measures of the Pact must be applied by individual countries, but the open method of coordination entails the "naming and shaming" of countries that fall behind. The European Commission has been put in charge of monitoring and to that end collects and publishes various indicator variables, including movements in unit labour costs, which capture the progress of individual countries.

The rationale behind the Euro Plus Pact is evident in its original name, the Competitiveness Pact, and also in its current subtitle: "Stronger economic policy coordination for competitiveness and convergence” (European Council 2011, p. 13). Deteriorating competiveness in individual countries is seen as a source of economic and financial instability. This view is directly stated in the conclusions from the European Council meeting at which the Euro Plus Pact was adopted (European Council 2011, p. 5):

The Euro Plus Pact [...] will further strengthen the economic pillar of EMU and achieve a new quality of policy coordination, with the objective of improving competitiveness and thereby leading to a higher degree of convergence [...].

The core of the Pact is the obligation of each participating country to retain external price competitiveness in order to avoid the build-up of financial imbalances, chiefly in the form of large current account deficits. This underlying economic "philosophy” is spelt out in Marzinotto (2011, p. 93):

Implicit to the design of the recent economic governance reform is the idea that southern European countries have accumulated large current account deficits because poor price competitiveness impeded them to export abroad.

The same point has been made by other commentators and analysts. ${ }^{3}$ The policymaking process meant that the Euro Plus Pact ended up including a large number of policy commitments regarding flexicurity, pension sustainability, health care, social benefits and tax policy coordination, but these measures are seen as instruments for improving external price competitiveness in individual member countries.

\footnotetext{
${ }^{3}$ One example is the succinct account in Gros (2011, p. 1): "The (relative) unit labour costs of GIP(S) countries Greece, Ireland, Portugal and Spain have increased: this is the fundamental cause of their problems as export performance must have been bad, pushing them into current account deficits.”
} 
The Euro Plus Pact has been subject to several policy-oriented analyses, especially in the months prior to and right after its adoption in March 2011. The policy discussion has brought up many important points relating to its underlying economic philosophy and to its practical implementation. Groll \& van Roye (2011) argue that it is the level of unit labour costs, not changes in these costs, which provides the most appropriate measure of the convergence that has been achieved. Gros \& Alcidi (2011) make a similar point and explain that the indices of relative unit labour costs can convey very different messages depending on the base year and the length of the sample that are used. They also argue that important issues have been left out of the Euro Plus Pact because measures to address the issues are politically inconvenient for the core countries in the euro area. ${ }^{4}$

Gros (2011) claims that the Euro Plus Pact is based on flawed economics as competitiveness indicators are weak predictors of future export performance; Estonia, for example, has had rapidly increasing relative unit labour costs but has also had strong export growth over extended periods of time. Wyplosz (2011) argues that it is inappropriate to focus on unit labour costs relative to euro area countries as more informative competitiveness measures would be found by comparison with the unit labour costs of all trading partners. Marzinotto (2011) is also critical of the underlying rationale of the Euro Plus Pact, but points out that a solution to the economic problems in the peripheral countries must include measures to strengthen their external price competitiveness. At the political level the Euro Plus Pact has been criticised by, among others, the Czech President Vaclav Klaus for further limiting the sovereignty of participating countries (Phillips 2011).

Other contributions to the debate on economic governance in the euro area or the EU consider the importance of capital flows within the region but without explicitly discussing the Euro Plus Pact. Holinski et al. (2012) find that the capital flows from North European to South European countries in the period 1992-2007 cannot be explained by

\footnotetext{
${ }^{4}$ Gros \& Alcidi (2011, p. 89) conclude: “The newly created Euro-Plus Pact has reinforced [...] the fallacy that because peripheral countries have lost competitiveness over the last year[s], this is the only problem that needs to be solved."
} 
fundamentals such as differentials in productivity growth and therefore have led to the accumulation of imbalances. The authors argue that systematic monitoring of external imbalances and improved policy coordination are advisable. De Grauwe (2011) argues that monetary unions are especially susceptible to fiscal crises as governments do not have access to inflationary financing and are therefore exposed to sudden changes in capital flows. Increased integration is also the favoured means of stabilising the euro area in this case. Gabrisch (2011) argues that additional coordination of economic policy is needed as market-induced capital flows bring about financial and economic imbalances, including wage cost divergences, because the region does not constitute an optimal currency area. This argument and the related literature propose a different understanding of the role and causes of competitiveness from that in the Euro Plus Pact.

In the context of the Euro Plus Pact the question is whether weak competitiveness leads to capital inflows (current account deficits) or whether capital inflows lead to weak competitiveness. Obviously the policy conclusions differ depending on the cause-effect relationships. The direction of causality is identified through the time dimension. We use Granger causality tests and vector autoregressive models with two variables, i.e. changes in the relative unit labour cost and changes in the current account balance (or just the current account balance in some specifications). In this way the paper can be seen to address the question: "What comes first, weak competitiveness or capital inflows?"

The empirical analyses are undertaken using a panel dataset comprising approximately 15 years of data for all 27 EU countries. The use of panel data makes reliable estimations possible in spite of the short time frame. The panel data estimations assume homogeneity of the slope coefficients across the countries in the sample, and the estimated slope coefficients or marginal effects may thus be seen as average values for all the countries in the sample. The Euro Plus Pact has been adopted by most EU countries and it is therefore reasonable to base assessments of the Pact on estimates of the average effects for all $27 \mathrm{EU}$ countries or different subsets of the 27 countries.

This paper is the first to discuss the contents and appropriateness of the Euro Plus Pact using an econometric analysis of the main causal assumption underlying the Pact. As such the paper contributes to the important discussion of the economic governance 
required in the euro area and the European Union at large. The issue discussed in the paper is, however, also of importance in its own right. The linkages between capital flows and the real exchange rate or other measures of competitiveness are widely debated, and there is a large literature that provides quantitative estimates of these linkages, particularly for emerging market economies (see the literature survey in Section 2). The paper contributes to this literature by providing estimates for the European Union and for different subsets of EU countries. The paper is also testing for causality in both directions, not only in one direction as typically seen. Finally, the use of VAR models is relatively unusual within this literature.

The rest of the paper is organised as follows: Section 2 discusses the existing literature on the links between competitiveness and capital flows. Section 3 presents the dataset, time series properties and various crossplots. Section 4 shows the results of simple Granger causality tests. Section 4 presents different VAR models and their impulse responses. Finally, Section 6 summarises the paper and draws some policy conclusions. 


\section{Competitiveness and external capital flows}

This section reviews and discusses some of the literature on the linkages between external capital flows and competitiveness. The, linkages in each direction are considered in separate subsections; we discuss first the direction from competitiveness to capital flows, then from capital flows to competitiveness. In each subsection some theoretical underpinnings are reviewed followed by brief surveys of empirical and policy-oriented studies.

It is of course something of a simplification to consider the direction of causality between competitiveness and external capital flows in isolation. There may for instance be factors that affect both the current account balance and the real exchange rate, e.g. the net foreign asset position, energy prices or economic policies (Obstfeld \& Rogoff 1995, Ostry 1988, Lartey 2008). ${ }^{5}$ In the discussion below it is argued, however, that there are likely to be many cases in which either competitiveness or external capital flows are affected by autonomous factors, i.e. factors that are independent of the other variable.

\subsection{From competitiveness to capital flows}

The theoretical starting point is the standard Keynesian model of an open economy in which net export is assumed to be a negative function of the real exchange rate, where the real exchange rate is defined as the price of domestic production relative to the price of foreign production measured in the same currency unit (Krugman \& Obstfeld 2003, ch. 16). The underlying assumption is that both domestic demand and export demand depend negatively - and strongly - on price. The Marshall-Lerner condition states that if the trade balance is initially in balance, the sum of the numerical values of the price elasticities of domestic and foreign demand must exceed one in order for a real depreciation to improve the trade balance and hence the current account balance. The

\footnotetext{
${ }^{5}$ The interaction between the two variables may also depend on the characteristics of the shocks affecting the economy, such as whether shocks are temporary or permanent and whether they are anticipated or unanticipated (Agenor 1998).
} 
numerical elasticities might be small in the short term because of long-term contracts and sluggish substitution, which implies that the trade balance deteriorates in the short term and only improve in the longer term, the celebrated $j$-curve effect.

Changes in the real exchange rate or unit labour costs can be autonomous in the sense that they do not depend on changes in external capital flows. This would be the case when factors like nominal exchange rates, productivity and nominal wage rates change because of exogenous factors. An example of this is changes in trade union power or labour market institutions that may affect nominal wage setting and/or productivity without any discernable impetus from external capital flows.

It is noticeable that the link from competitiveness to the current account balance is also at the core of many concepts of an equilibrium exchange rate (Williamson 1985, 1994). The equilibrium exchange rate is then taken to be the real exchange rate - or another suitable indicator of international competitiveness - that is compatible with a desired current account balance. This is for instance the case in the Macroeconomic Balance Framework used by the International Monetary Fund to access misalignment of the real exchange rate (Isard et al. 2001, Isard 2007). The real exchange rate is seen to be misaligned if it differs markedly from the estimated equilibrium value over a period of time. The real exchange rate is overvalued if it is associated with excessive current account deficits; it is presumed that a depreciation of the real exchange rate will improve the current account balance.

A large number of studies have examined the hypothesis of a link from competitiveness to current account developments, using datasets from both developed and developing economies. The general conclusion is that the effect is non-existent or very subdued in the short term, but that the effect might be more pronounced in the longer term. There seems, however, to be some heterogeneity across the sample countries.

Rose (1991) finds that the hypothesis of a link from the real exchange rate to the trade balance gains little support in a sample of five OECD countries and conjectures that the numerical import and export price elasticities are small. Bachman (1992) finds that measures of competitiveness have very little explanatory power for the current account balance in the USA. Bahmani-Oskooee \& Kara (2003) estimate co-integration models 
for nine industrialised countries and reach the conclusion that there is no consistent finding; the reaction of the trade flows to changes in import and export prices varies substantially across the countries.

Boyd et al. (2008) use a sample of eight OECD countries and find from cointegration analyses that there is an effect from the real exchange rate on the trade balance in most of the sample countries. The effect emerges, however, after a substantial delay, providing support for the $j$-curve effect.

After the outbreak of the global financial crisis, many studies have discussed a possible link from competitiveness to the trade or current account balance in euro area members. The results of the studies are mixed and occasionally difficult to interpret.

Zemanek et al. (2009) argue that a lack of international competitiveness can explain the large current account deficits observed in some euro area countries. Interestingly the empirical results do not support this viewpoint to any larger extent; in estimations of bilateral trade balances between individual trading partners the measure of changes in the unit labour cost appears to have little or no explanatory power. Instead other variables, largely reflecting the macroeconomic stance, appear to be of importance.

Jaumotte \& Sodsriwiboon (2010) argue that the real exchange rate in the South European euro countries was substantially overvalued relative to its equilibrium value at the onset of the global financial crisis. The argument is, however, based on the current account balances in the countries being above levels deemed sustainable under various criteria and the analysis is therefore not able to detect the direction of causality.

Belke \& Dreger (2011) investigate the relative importance of competiveness and income convergence for the current account in 11 euro area countries. The current account balance, the relative real effective exchange rate and the relative income level are all found to exhibit unit roots and to be co-integrated. An appreciation of the relative real effective exchange rate is associated with a worsening of the current account balance. Belke \& Dreger (2011) do not present the results of the short-term adjustment for the long-term equilibrium relation, but nevertheless state that "[i]f the relative real effective exchange rate appreciates, the current account will worsen”. 
Many studies have drawn attention to deteriorating competitiveness in countries in the geographical periphery of Europe. Fischer (2007) uses various concepts of real equilibrium exchange rates and finds that Germany gained competitiveness and several South European countries lost competitiveness between the introduction of the euro in January 1999 and the end of 2005. It is concluded that these developments to some extent reversed previously existing disparities. Dullien \& Fritsche (2008) also find that several South European countries have seen rapid increases in unit labour costs and, furthermore, that deviations from a long-term equilibrium level have only closed very slowly. Wage restraint is often seen as a means of improving competitiveness and avoiding the build-up of current account imbalances. Stockhammer (2011, p. 91) sums up this view: “...wage policy has a critical role in the rebalancing of European economies”.

\subsection{From capital flows to competitiveness}

The main explanation of a link from capital flows to competitiveness is the Dutch disease theory (Sy \& Tabarraei 2009, Edwards 1988, Corden \& Neary 1982). The models typically assume two traded goods, an import good and an export good, and one non-traded good. External capital flows imply that traded resources are made available or taken away. Consider an inflow of capital caused by some autonomous factor such as lower international interest rates. The capital inflow makes additional resources available for domestic absorption such as consumption and investment, and this increased demand will typically be directed towards both traded and non-traded goods. While the prices of the traded goods are determined from abroad, the increased demand for the non-traded good will drive its price up (since the marginal return of production factors in limited supply, such as labour, will increase). Ultimately the result of the capital inflow is worsened competitiveness as measured by higher unit labour costs or an appreciation of the real exchange rate (the price of traded goods relative to the price of non-traded goods). Evidently an autonomous capital outflow will have the opposite effect as lower demand for non-traded goods will lead to lower unit labour costs or a real depreciation. 
This discussion makes clear that the effect of an autonomous capital inflow will depend on the characteristics of the recipient economy. It will depend on how the increased demand is divided between traded and non-traded goods and it may also depend on the distribution between consumption and investment and the distribution of investment between the traded and non-traded sectors. Ceteris paribus, the real appreciation is likely to be smaller if the capital inflow is spent on productivity-enhancing investments in the non-traded sector as the effect of increased returns to domestic production factors will be counteracted by higher productivity of the same factors.

It is apparent that external capital flows can be autonomous and independent of the state of competitiveness of the economy. The financial fragility hypothesis by Minsky (1982, pp.117-162) suggests that boom-bust cycles in financial markets can be caused by “euphoric expectations". This may be particularly relevant in the case of Europe where the introduction of the euro and integration of Central and Eastern Europe may have been triggers for the build-up of euphoric expectations in the sense used by Minsky (Gabrisch 2011). ${ }^{6}$

The causation from capital flows to competiveness has a long history in literature, and starts with Böhm-Bawerk’s (1924) famous statement that the capital balance rules the trade balance and not vice versa. Keynes emphasised the destabilising effects of external capital flows. In the Keynes-Ohlin controversy about the transfer paradox, Keynes argued that the reparations Germany had to pay after World War I would worsen the long-term competitiveness of the recipient countries through a negative terms-of-trade effect or, equivalently, an appreciation of the real exchange rate (Keynes 1929). ${ }^{7}$ The debate was revived after German unification in 1990 , when large transfers went from Western to Eastern Germany.

\footnotetext{
${ }^{6}$ Jaumotte \& Sodsriwiboon (2010) analyse the growing current account deficits in the euro area countries in Southern Europe prior to the global financial crisis. The deficits were partly the result of financial integration leading to lower interest rates in those countries and consequently lower savings while investments were holding up, but the effect on the current account deficits was larger than that which could be explained by fundamentals.

${ }^{7}$ In the early 1940s, Keynes proposed a common currency, the Bancor, plus a clearing union in order to deal with excessive debit balances (Keynes 1942, p. 20).
} 
The empirical evidence is mixed. Calvo et al. (1993) show that countries in Latin American at different times experienced episodes of substantial capital inflows and the result was real appreciations. The capital inflows occurred in countries with very diverse economic conditions, suggesting that the capital flows were in large part driven by events outside the region. Calvo et al. (1996) show that developments in both Asian and Latin American countries in the late 1980s and early 1990s were consistent with the Dutch disease hypothesis. The papers did not apply formal econometric testing. Rajapatirana (2003) uses data for the period 1985-2000 and reaches the same conclusion as Calvo et al. (1996), but also finds that the real appreciation following net capital inflows was much larger in Latin American countries than in Asian countries, possibly because of the different composition of the capital flows.

Bakardzieva et al. (2010) found for a panel of emerging market economies, including Eastern European countries, that net total capital inflows led to an appreciation of the real effective exchange rate, which is in accordance with the Dutch disease hypothesis. The effects, however, differed depending on the type of capital flow. For most types of capital (portfolio investment, loans, foreign aid, remittances or income transfers), a capital inflow led to a real appreciation, but this was generally not the case for capital stemming from foreign direct investments.

Saborowski (2009) use a broad sample of 84 countries during the period 1990-2006 to investigate the effect of capital flows on the real exchange rate. The study finds that capital inflows in the form of FDI generally lead to an appreciation of the real exchange rate. Importantly, the tendency towards real appreciation is attenuated if the recipient country has a highly developed financial sector.

Morande (1988) tests whether real appreciation came before foreign capital inflows or vice versa in Chile. The analysis is based on small VAR models estimated on monthly data for the period $1977-83$. The conclusion is that the direction of causality is from capital inflows to real exchange rate appreciation.

The importance of capital flows on competitiveness and financial stability has received little emphasis in the European governance reform debate. Perez-Caldenty \& Vernengo (2012) argue that the large current account surpluses in the core euro count- 
ries contributed to the misalignment of real exchange rates within Europe. Schnabl \& Zemanek (2011) similarly highlight current account trends within Europe and the possible destabilising consequences.

\subsection{Direction of causality}

The literature on international competitiveness and the current account balance includes simple and straightforward theories explaining causation in both directions. Moreover, there are empirical studies finding a link from competitiveness measures to the current account balance and numerous other studies establishing a link in the opposite direction. It is noticeable, however, that very few empirical studies include tests that allow for causation in both directions, the main exception being Morande 1988, and this omission limits the policy conclusions that can be drawn from the studies. The overall conclusion is that it is not possible ex ante to ascertain the direction of causality; only empirical studies on a specific sample can provide such information. 


\section{Data and time series properties}

The dataset used in the empirical analysis is a panel of annual data from 1995 until 2011 for the $27 \mathrm{EU}$ countries. The panel is unbalanced as observations of unit labour costs at the beginning of the sample are missing for some countries. The variables used in the empirical analysis follow closely from the discussion of the Euro Plus Pact in Section 1. The Pact aims to restrain the growth of unit labour costs in order to prevent current account imbalances. All data were downloaded from the Eurostat database on 11 May 2012.

The variable GRULC denotes the percentage growth of the unit labour cost in the individual EU country relative to the percentage growth of the unit labour cost in the EA12, i.e. the euro area comprising the first 12 participating countries. ${ }^{8}$ The unit labour cost is in both cases expressed in terms of common currency units (ECU/EUR). The variable is computed from an index of the nominal unit labour cost, which is defined as the ratio between the nominal compensation per employee and the productivity per employee, all expressed in local currency (Eurostat classifier nama_aux_ulc). ${ }^{9}$ An increase in the relative unit labour cost, GRULC $>0$, signifies a worsening of price competitiveness relative to the EA12, while a lowering of the relative unit labour cost, GRULC $<0$, signifies an improvement in competitiveness relative to the EA12.

Two additional competitiveness variables are included in the dataset for use in robustness analyses. One variable is GREER_ULC, which is the percentage change in the real effective exchange rate against 36 trading partners deflated using the unit labour cost in the total economy (classifier: ert_eff_ic_a). The other variable is GREER_CPI which is the percentage change in the real effective exchange rate against 36 trading partners deflated using consumer price indices (classifier: ert_eff_ic_a).

\footnotetext{
${ }^{8}$ GRULC is not available for Greece and Malta for 1996-2000 and for Romania for 1996-1999 due to missing source data.

${ }^{9}$ For the euro area countries Eurostat expresses the nominal unit labour cost as "euro fixed" values for the years prior to the introduction of the euro, i.e. data in the national currency values are converted to EUR/ECU values using the irrevocably fixed exchange rate at the time of the introduction of the euro. The use of fixed conversion factors rules out comparison across countries and the euro fixed values are therefore converted into EUR/ECU values using the market exchange rates of the national currencies against EUR/ECU (classifier ert_bil_conv_a). For the 10 countries outside the euro area, the nominal unit labour cost is converted to ECU/EUR using the nominal exchange rates (classifier ert_bil_eur_a).
} 
As is customary in the literature, the capital flow variable is taken to be the current account balance (Reinhart \& Reinhart 2009). By definition, the sum of the current account balance, the financial account balance and the reduction in official reserves is (approximately) nil, where the financial account balance is the sum of net foreign direct investment, net portfolio investment and net other investment (loans etc.). The current account balance is typically measured more precisely and more consistently than components of the financial balance. ${ }^{10}$

The current account balance as a percentage of GDP is denoted CA (classifier bop_q_gdp). A current account surplus, CA $>0$, is tantamount to a net capital outflow and indicates the accumulation of net foreign assets. A current account deficit, CA $<0$, shows a net capital inflow and implies a deterioration in the net foreign asset position. In the baseline specifications, the change in the current account, DCA = CA - CA(-1), is used.

The time series properties of the data series are important for the choice of empirical methodology. Table 1 shows the results of panel data unit root tests, with common and with country-specific roots, for the data series GRULC, CA and DCA. The result is that GRULC is panel stationary, CA is a borderline case, and DCA, the first difference of CA, is panel stationary. The borderline result for CA and the clear stationarity of DCA suggest that it is judicious to use both panel series in the econometric analyses.

\footnotetext{
${ }^{10}$ A current account deficit is financed through a financial account surplus and/or a reduction in official reserves. Reinhart \& Reinhart (2009) argue that the measure of capital flows should ideally be computed as the current account balance plus the reduction in official reserves. One argument for removing changes in official reserves is that that they are the result of administrative, non-private, decision making. It is noticeable, however, that foreign direct investment, portfolio investment and other investment also often include non-private flows. In any case, a current account deficit implies that more resources are made available for domestic absorption than would otherwise have been the case.
} 
Table 1 Tests of unit roots of panel data series, $1995-2011$

\begin{tabular}{|lcccc|}
\hline & ${\text { Levin, Lin \& } \text { Chu }^{\mathbf{a}}}^{\mathbf{2}}$ & Im, Pesaran and Shin $^{\mathbf{b}}$ & ADF-Fisher $^{\mathbf{b}}$ & PP-Fisher $^{\mathbf{b}}$ \\
\hline \multirow{2}{*}{ GRULC } & -10.318 & -8.573 & 178.519 & 240.968 \\
& {$[0.000]$} & {$[0.000]$} & {$[0.000]$} & {$[0.000]$} \\
\hline \multirow{2}{*}{ CA } & -2.070 & -1.407 & 70.658 & 67.010 \\
& {$[0.019]$} & {$[0.080]$} & {$[0.064]$} & {$[0.110]$} \\
\hline \multirow{2}{*}{ DCA } & -7.678 & -8.457 & 172.421 & 316.066 \\
& {$[0.000]$} & {$[0.000]$} & {$[0.000]$} & {$[0.000]$} \\
\hline
\end{tabular}

a The test assumes a common unit root across the countries. ${ }^{\mathrm{b}}$ The test allows for different unit roots across the countries.

Notes: The null hypothesis is in all cases that the variable has a unit root. The tests allow for countryspecific intercepts in the test regressions. The values in square brackets are $p$-values.

Figure 1 Crossplots between the change in the relative unit labour cost and the current account balance, and changes in the current account balance; annual data 1995 - 2011, 27 EU countries
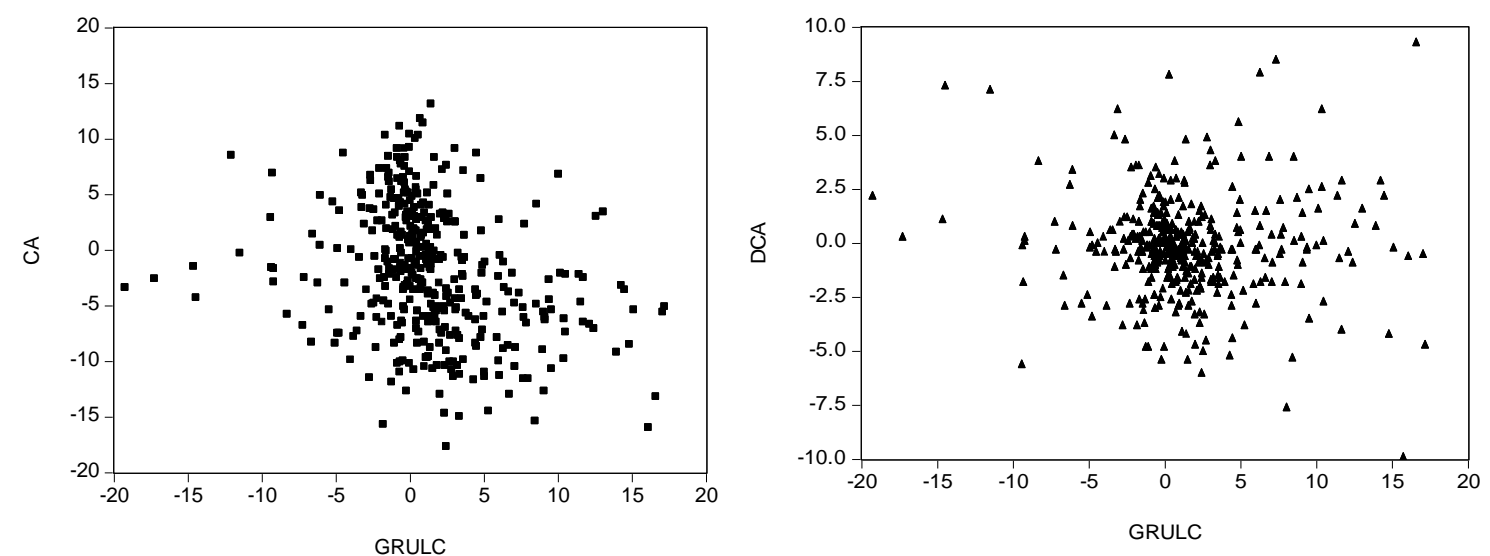

Note: GRULC is the change in the relative unit labour cost as a percentage, CA is the current account balance as a percentage of GDP, DCA is the change in the current account balance in percentage points of GDP. In total 10 observations for which GRULC is below -20 or above 20 or CA is below -20 or above 20 have been omitted.

Figure 1 shows crossplots of the growth in the relative unit labour cost GRULC and the current account balance CA or the change in the current account balance DCA for all 27 EU countries for the period 1995-2011, the scales being chosen so that a few extreme 
observations have been left out. Both crossplots exhibit weak negative correlations, but no clear patterns are apparent. Moreover, the possible directions of causality cannot be ascertained without additional identifying assumptions. 


\section{Granger causality tests}

The discussion in Section 2 suggests that the possible effect of competitiveness on the current account is likely to occur with a time lag ( $j$-curve effect) and, conversely, the possible effect of the current account on competitiveness may also appear with a time lag, especially in cases with a fixed exchange rate. It is therefore reasonable to identify the direction of causality using the time dimension, i.e. causality is associated with the lagged values of a variable having explanatory power over the other variable. ${ }^{11}$

This section presents the results of the Granger causality tests. The aim is to test for time-based causality between the two variables of interest, i.e. between GRULC, the percentage growth in the relative unit labour cost, and DCA, the change in the current account balance in percentage points of GDP. Tests are run for a large number of specifications and for different country groups in order to examine the robustness of the results. A robustness test in which GRULC and the current account balance CA are used can be found in Appendix A.

The Granger causality test is run in a model in which the dependent variable is explained both by lags of itself and lags of an independent explanatory variable (and possibly control variables). The Granger causality test is a standard Wald test with the null hypothesis that the coefficient or coefficients of the lagged independent explanatory variable are zero. The test statistic follows an F-distribution and asymptotically a $\chi^{2}$ distribution. If the null hypothesis is rejected, the lagged variable is said to Granger cause the other variable.

To avoid outliers unduly affecting the results, a few extreme observations have been trimmed from the dataset. Observations in which GRULC is below -20 or above 20 and observations for which CA is below -20 or above 20 have been omitted. These observations typically relate to episodes of extreme inflation, stabilisation of extreme inflation or cases of extreme financial instability. In total, 10 observations have been omitted due

\footnotetext{
11 Morande (1988) also seeks to test for time-based (Granger) causality using different VAR models including variables such as the real exchange rate and external capital flows. The methodology is also tangential to the co-integration analysis in Belke \& Dreger (2011) although the latter does not seek to identify the direction of causality.
} 
to this trimming of the dataset. The results are generally not very sensitive to the specific choice of cut-off points; the results presented below will change only marginally if the low cut-off point is taken to be -15 and the high cut-off point to be 15 .

Table 2 shows the results of panel data estimations used to test whether lags of DCA have explanatory power towards GRULC when one or more lags of GRULC are included, i.e. to test whether GRULC Granger causes DCA. Column (2.1) shows a simple estimation with country fixed effects and one lag of both variables. The null hypothesis of no explanatory power of GRULC cannot be rejected. The same applies in Column (2.2) in which the fixed effects are omitted and the model is estimated using ordinary least squares.

Table 2 Panel data Granger causality tests. Dependent variable DCA

\begin{tabular}{|c|c|c|c|c|c|c|}
\hline & (2.1) & (2.2) & (2.3) & (2.4) & (2.5) & (2.6) \\
\hline $\operatorname{DCA}(-1)$ & $\begin{array}{c}0.130 \\
(0.069)\end{array}$ & $\begin{array}{c}0.143 \\
(0.101)\end{array}$ & $\begin{array}{c}0.144 \\
(0.054)\end{array}$ & $\begin{array}{c}0.115 \\
(0.092)\end{array}$ & $\begin{array}{c}-0.061 \\
(0.141)\end{array}$ & $\begin{array}{c}0.188 \\
(0.117)\end{array}$ \\
\hline DCA(-2) & .. & .. & .. & $\begin{array}{c}-0.221 \\
(0.046)\end{array}$ & $\begin{array}{c}0.061 \\
(0.057)\end{array}$ & $\begin{array}{c}-0.241 \\
(0.057)\end{array}$ \\
\hline GRULC(-1) & $\begin{array}{c}0.059 \\
(0.046)\end{array}$ & $\begin{array}{c}0.064 \\
(0.038)\end{array}$ & $\begin{array}{c}0.132 \\
(0.063)\end{array}$ & $\begin{array}{c}0.051 \\
(0.038)\end{array}$ & $\begin{array}{c}-0.058 \\
(0.094)\end{array}$ & $\begin{array}{c}0.055 \\
(0.046)\end{array}$ \\
\hline GRULC(-2) & .. & .. & .. & $\begin{array}{c}0.044 \\
(0.035)\end{array}$ & $\begin{array}{c}0.017 \\
(0.061)\end{array}$ & $\begin{array}{c}0.061 \\
(0.043)\end{array}$ \\
\hline Granger causality $^{\mathrm{a}}$ & $\begin{array}{c}1.60 \\
{[0.217]}\end{array}$ & $\begin{array}{c}2.84 \\
{[0.093]}\end{array}$ & $\begin{array}{c}4.36 \\
{[0.037]}\end{array}$ & $\begin{array}{c}1.15 \\
{[0.333]}\end{array}$ & $\begin{array}{c}0.20 \\
{[0.826]}\end{array}$ & $\begin{array}{c}1.42 \\
{[0.264]}\end{array}$ \\
\hline Time sample & 1997-2011 & 1997-2011 & 1998-2011 & 1998-2011 & 1998-2011 & 1998-2011 \\
\hline Countries & EU27 & EU27 & EU27 & EU27 & EA12 & CEE \\
\hline Observations & 381 & 381 & 381 & 356 & 163 & 128 \\
\hline Estimation & $\mathrm{FE}$ & OLS & $\begin{array}{c}\text { System } \\
\text { GMM }\end{array}$ & FE & FE & $\mathrm{FE}$ \\
\hline
\end{tabular}

a The null hypothesis of the Granger causality test is that the lagged value(s) of the independent explanatory variable do(es) not Granger cause the dependent variable. The test statistic is F-distributed except in the case of the System GMM estimation in which it is $\chi^{2}$-distributed; the values in square brackets are $p$-values.

Notes: Standard errors are clustered along the cross section and are shown in round brackets. A constant term is included in all estimations but not shown. 
The presence of a lagged dependent variable gives rise to potentially biased estimates when fixed effect estimation is used (Nickel bias). The model is therefore estimated using the System GMM methodology developed by Arellano \& Bover (1995) and Blundell \& Bond (1998). Both the lagged dependent variable and the lagged independent explanatory variable are instrumented using expanding lags in both cases. The estimated coefficients are qualitatively similar to those obtained using fixed effects ordinary least squares. The hypothesis of no Granger causality can be rejected at the $5 \%$ level (although not at the 1\% level), but the sign of the coefficient of GRULC(-1) is positive, not negative as expected.

Column (2.4) shows the results when two lags of both variables are introduced as explanatory variables. In this case Granger causality entails the rejection of the joint hypothesis that the coefficients of GRULC(-1) and GRULC(-2) are zero. The hypothesis cannot be rejected ( $p$-value $=0.333$ ), suggesting that the inclusion of two lags of changes in the unit labour cost does not change the results obtained previously. Column (2.5) shows the results when the sample is restricted to the EA12 countries, i.e. the first 12 countries that joined the euro area, and Column (2.6) shows the results when the sample is restricted to the 10 CEE countries. The result in both cases is that the null hypothesis cannot be rejected.

Table 3 shows the results when the change in the relative unit labour cost, GRULC, is explained by autoregressive terms and lagged changes in the current account balance, DCA. Column (3.1) shows the results when one lag is included and the panel is estimated using fixed effects. The lagged current account balance has substantial explanatory power; an increase in the change of the current account balance ("capital outflow”) of one percentage point of GDP is associated with 0.397 percent lower growth in the unit labour cost the following year, i.e. a considerable improvement in international competitiveness. By the same token, a capital inflow leads to deteriorating competitiveness the following year. Similar results follow from the OLS estimation in Column (3.2) and the System GMM estimation in Column (3.3). 
Table 3 Panel data Granger causality tests. Dependent variable GRULC

\begin{tabular}{|c|c|c|c|c|c|c|}
\hline & (3.1) & (3.2) & (3.3) & (3.4) & (3.5) & (3.6) \\
\hline DCA(-1) & $\begin{array}{c}-0.397 \\
(0.109)\end{array}$ & $\begin{array}{c}-0.378 \\
(0.089)\end{array}$ & $\begin{array}{c}-0.462 \\
(0.161)\end{array}$ & $\begin{array}{c}-0.300 \\
(0.113)\end{array}$ & $\begin{array}{c}-0.217 \\
(0.097)\end{array}$ & $\begin{array}{c}-0.321 \\
(0.156)\end{array}$ \\
\hline DCA(-2) & .. & .. & .. & $\begin{array}{c}-0.282 \\
(0.079)\end{array}$ & $\begin{array}{c}-0.305 \\
(0.086)\end{array}$ & $\begin{array}{c}-0.360 \\
(0.098)\end{array}$ \\
\hline GRULC(-1) & $\begin{array}{c}0.072 \\
(0.054)\end{array}$ & $\begin{array}{c}0.117 \\
(0.060)\end{array}$ & $\begin{array}{c}0.122 \\
(0.061)\end{array}$ & $\begin{array}{c}0.671 \\
(0.050)\end{array}$ & $\begin{array}{c}0.230 \\
(0.101)\end{array}$ & $\begin{array}{c}0.046 \\
(0.059)\end{array}$ \\
\hline GRULC(-2) & .. & .. & .. & $\begin{array}{c}-0.148 \\
(0.048)\end{array}$ & $\begin{array}{c}-0.113 \\
(0.054)\end{array}$ & $\begin{array}{c}-0.168 \\
(0.062)\end{array}$ \\
\hline Granger causality $^{\mathrm{a}}$ & $\begin{array}{c}13.34 \\
{[0.001]}\end{array}$ & $\begin{array}{l}17.88 \\
{[0.000]}\end{array}$ & $\begin{array}{c}8.25 \\
{[0.004]}\end{array}$ & $\begin{array}{c}8.40 \\
{[0.002]}\end{array}$ & $\begin{array}{c}6.34 \\
{[0.015]}\end{array}$ & $\begin{array}{c}8.61 \\
{[0.008]}\end{array}$ \\
\hline Time sample & 1997-2011 & 1997-2011 & 1998-2011 & 1998-2011 & 1998-2011 & 1998-2011 \\
\hline Countries & EU27 & EU27 & EU27 & EU27 & EA12 & CEE \\
\hline Observations & 381 & 381 & 381 & 356 & 163 & 128 \\
\hline Estimation & FE & OLS & $\begin{array}{c}\text { System } \\
\text { GMM }\end{array}$ & FE & FE & FE \\
\hline
\end{tabular}

${ }^{a}$ The null hypothesis of the Granger causality test is that the lagged value(s) of the independent explanatory variable do(es) not Granger cause the dependent variable. The test statistic is F-distributed except in the case of the System GMM estimation in which it is $\chi^{2}$-distributed; the values in square brackets are $p$-values.

Notes: Standard errors are clustered along the cross section and are shown in round brackets. A constant term is included in all estimations but not shown.

Column (3.4) shows the results when two lags are included. The coefficients of the two lags of the current account variable are both negative. They are highly significant in both economic and statistical terms. The null hypothesis of no explanatory power of the two lags of the current account is rejected, i.e. changes in the current account Granger cause changes in the relative unit labour costs. Column (3.5) shows the results when the sample comprises the EA12 countries and Column (3.6) shows the results for the sample of CEE countries. In these samples too, the estimated coefficients of the lagged changes in the current account balance are negative; changes in current account balance are found to Granger cause changes in the relative unit labour cost. 
The conclusions from the Granger causality tests in Tables 2 and 3 are clear. Lags of GRULC do not help explain DCA in estimations in which lags of DCA are included. In other words, changes in the relative unit labour cost do not Granger cause changes in the current account balance. This holds across different samples of countries and across a number of estimation methodologies. In contrast to these results, lags of DCA appear in most cases to have substantial explanatory power over changes in GRULC in models where lags of GRULC are included. In other words, changes in the current account balance Granger cause changes in the relative unit labour cost. This implies that for instance an increasing inflow of capital (a deteriorating current account balance) leads to deteriorating competitiveness.

The estimations presented in Tables 2 and 3 were made using the change in the relative unit labour cost, GRULC, and the change in the current account balance, DCA. As argued earlier, it may also be of interest to examine possible Granger causality between GRULC and the level of the current account balance, CA. Tables A1 and A2 in Appendix A show the results when the estimations in Tables 2 and 3 are made using the level of the current account balance, CA, instead of its change, DCA.

In qualitative terms most of the results remain unchanged. Table A1 shows the results of estimations in which changes in the current account balance are explained by autoregressive terms and lagged changes in the relative unit labour cost. Lagged changes in the relative unit labour cost do not Granger cause the current account balance, irrespective of the sample or estimation method.

Table A2 presents the results of estimations where the dependent variable is the change in the relative unit labour cost. In most specifications the level of the lagged current account balance is found to Granger cause changes in the relative unit labour cost at least at the $10 \%$ level of statistical significance. The exception is the case where the sample consists only of the EA12 countries and two lags are used. The coefficients of the two lags of the current account variable attain different signs and the sum is close to zero. The complicated structure of both negative and positive coefficients may be associated with the CA variable being a borderline case between stationarity and exhibiting a unit root. For the CEE countries the null hypothesis of no link from the lagged current account levels to changes in the relative unit labour cost is strongly rejected. 
Another robustness test was carried out with the change in the relative unit labour cost replaced by two different measures of changes in competitiveness, the change in the real effective exchange rate deflated by the unit labour cost, and the same deflated by the consumer price index (GREER_ULC, GREER_CPI). The results are not shown. In both cases the main results were the same as when GRULC was used, i.e. competitiveness does not Granger cause changes in the current account, but changes in the current account do seem to Granger cause the competitiveness measure. This finding is not surprising as the three variables GRULC, GREER_ULC and GREER_CPI are closely correlated. The upshot is that the specific choice of competitiveness measure is of little importance when assessing the relation between competitiveness and external capital flows. 


\section{VAR models}

This section extends the analysis in Section 4 by modelling changes in relative price competitiveness and the current account balance in a vector autoregressive (VAR) model. This allows a deeper investigation of the interactions between the two variables over time. In particular, the reaction of the two variables to shocks can be computed using different assumptions for the temporal relation between the variables, including no lag between the change in one variable and the resulting change in the other variable. We will focus on changes in the relative unit labour cost, GRULC, and changes in the current account balance, DCA. Both variables are panel stationary.

Table 4 Estimation of panel VAR models, GRULC and DCA

\begin{tabular}{|c|c|c|c|c|c|c|}
\hline & \multicolumn{2}{|c|}{ (4.1) } & \multicolumn{2}{|c|}{$(4.2)$} & \multicolumn{2}{|c|}{ (4.3) } \\
\hline & DCA & GRULC & DCA & GRULC & DCA & GRULC \\
\hline DCA(-1) & $\begin{array}{c}0.115 \\
(0.092)\end{array}$ & $\begin{array}{c}-0.300 \\
(0.113)\end{array}$ & $\begin{array}{c}-0.061 \\
(0.141)\end{array}$ & $\begin{array}{c}-0.217 \\
(0.097)\end{array}$ & $\begin{array}{c}0.188 \\
(0.117)\end{array}$ & $\begin{array}{c}-0.321 \\
(0.156)\end{array}$ \\
\hline DCA(-2) & $\begin{array}{c}-0.221 \\
(0.046)\end{array}$ & $\begin{array}{c}-0.282 \\
(0.079)\end{array}$ & $\begin{array}{c}0.061 \\
(0.057)\end{array}$ & $\begin{array}{c}-0.305 \\
(0.086)\end{array}$ & $\begin{array}{c}-0.241 \\
(0.057)\end{array}$ & $\begin{array}{c}-0.360 \\
(0.098)\end{array}$ \\
\hline GRULC(-1) & $\begin{array}{c}0.051 \\
(0.038)\end{array}$ & $\begin{array}{c}0.671 \\
(0.050)\end{array}$ & $\begin{array}{c}-0.058 \\
(0.094)\end{array}$ & $\begin{array}{c}0.230 \\
(0.101)\end{array}$ & $\begin{array}{c}0.055 \\
(0.046)\end{array}$ & $\begin{array}{c}0.046 \\
(0.059)\end{array}$ \\
\hline GRULC(-2) & $\begin{array}{c}0.044 \\
(0.035)\end{array}$ & $\begin{array}{c}-0.148 \\
(0.048)\end{array}$ & $\begin{array}{c}0.017 \\
(0.061)\end{array}$ & $\begin{array}{c}-0.113 \\
(0.054)\end{array}$ & $\begin{array}{c}0.061 \\
(0.043)\end{array}$ & $\begin{array}{c}-0.168 \\
(0.062)\end{array}$ \\
\hline$R^{2}$ & 0.129 & 0.219 & 0.042 & 0.281 & 0.167 & 0.221 \\
\hline Time sample & \multicolumn{2}{|c|}{ 1998-2011 } & \multicolumn{2}{|c|}{ 1998-2011 } & \multicolumn{2}{|c|}{ 1998-2011 } \\
\hline Countries & \multicolumn{2}{|c|}{ EU27 } & \multicolumn{2}{|c|}{ EA12 } & \multicolumn{2}{|c|}{ CEE } \\
\hline Observations & \multicolumn{2}{|c|}{381} & \multicolumn{2}{|c|}{163} & \multicolumn{2}{|c|}{128} \\
\hline
\end{tabular}

Notes: Standard errors are shown in round brackets. Fixed effects are included in all estimations but are not reported.

Even allowing for simultaneous dependence between the two variables GRULC and DCA, the system can be reduced so as to contain only lags of the two variables as explanatory variables. Estimations are made using two lags and considering three diffe- 
rent country samples: all 27 EU countries, the EA12 countries and the 10 CEE countries. The results of the system estimations, presented in Table 4, correspond to the results in Columns (2.4)-(3.4), (2.5)-(3.5) and (2.6)-(3.6). ${ }^{12}$

Across all three country samples, the lags of GRULC exert little explanatory power on DCA, while lags of DCA exert substantial explanatory power on GRULC, both in statistical and economic terms. The coefficients of determination also vary across the equations in the systems as they are higher for GRULC estimations than for the DCA estimations. For the EA12 countries the lagged dependent and the independent explanatory variables have essentially no explanatory power in the case of DCA $\left(R^{2}=\right.$ 0.042). This is a further indication that changes in the relative unit labour cost have little effect on the current account balance.

This paper seeks to ascertain the most probable direction of causality between the two main variables of interest, GRULC and DCA. The Granger causality tests in Section 4 assumed that, irrespective of the direction of causality, the effect would occur with a lag of one year or more. The VAR model allows a more sophisticated identification of cause and effect. We will consider three different identification schemes, which entail different causal dynamics between the two variables of interest.

a) There are no contemporaneous effects between the two variables, only lagged effects. This is a case of over-identification as all off-diagonal elements in the variance-covariance matrix are zero (non-orthogonalisation).

b) GRULC can affect DCA contemporaneously, while DCA can only affect GRULC with a lag. This is a case of exact recursive identification based on Cholesky decomposition of the variance-covariance matrix.

c) DCA can affect GRULC contemporaneously, while GRULC can only affect DCA with a lag. This is another case of Cholesky decomposition but with the opposite direction of temporal effects from those in b).

\footnotetext{
${ }^{12}$ The estimations of the panel VAR systems are undertaken in Eviews, and the econometrics software does not allow clustering of the standard errors; the ordinary standard errors are generally somewhat smaller than the clustered standard errors.
} 
Figures 2-3 present impulse responses for model (4.1) estimated on the full sample of all 27 EU countries using the three different identification schemes a)-c).

Figure 2 Response of DCA and GRULC to innovations in GRULC and DCA, non-factorised innovations, 27 EU countries

Response of DCA to DCA

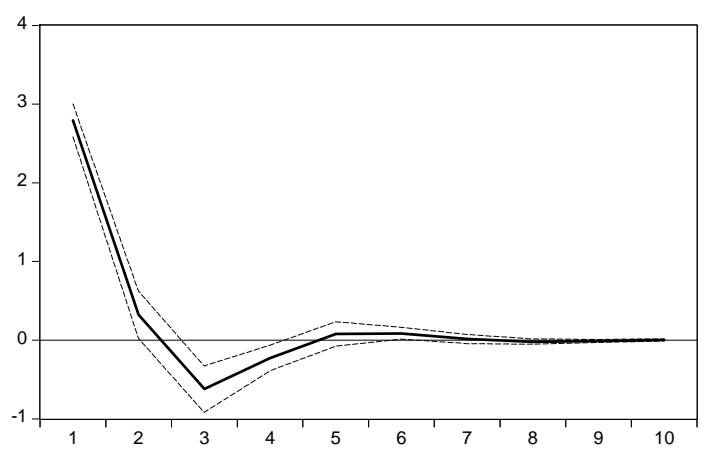

Response of GRULC to DCA

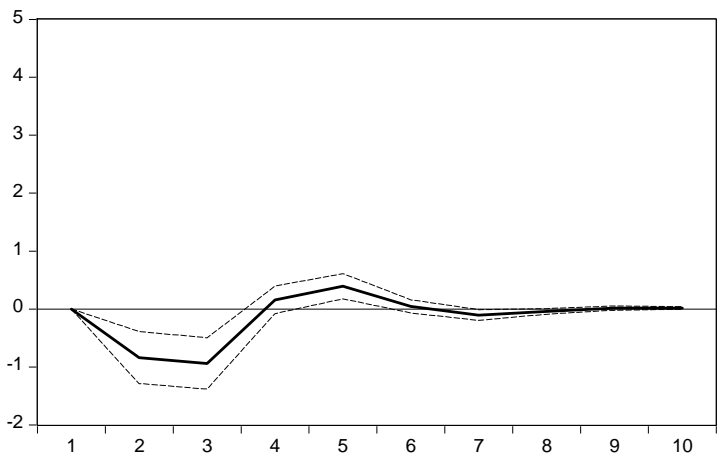

Response of DCA to GRULC

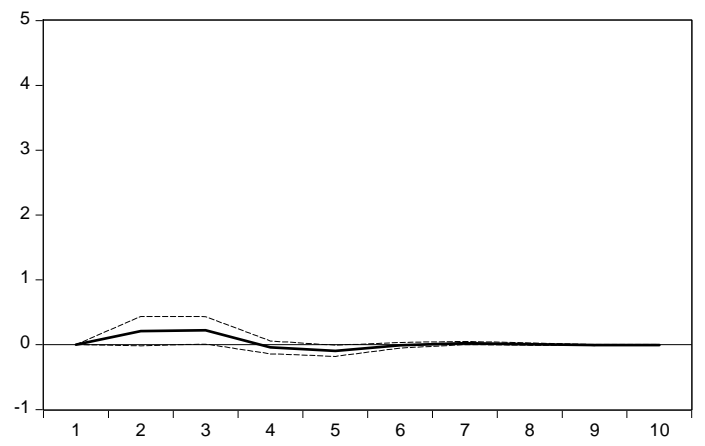

Response of GRULC to GRULC

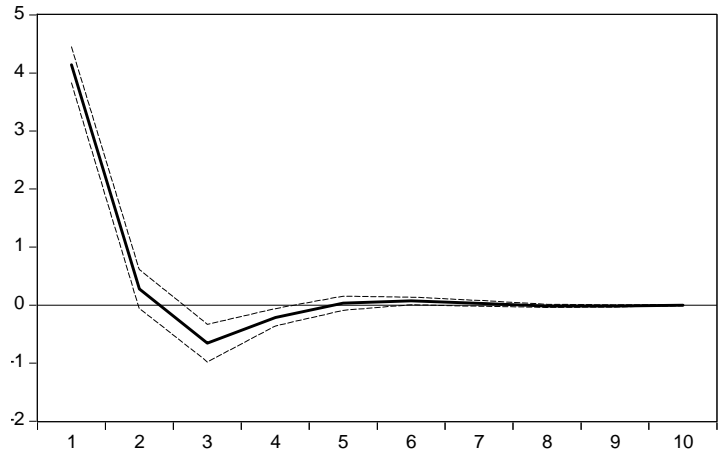

(a) Non-factorised innovations

Note: The solid line depicts the impulse response and the dashed lines the \pm two standard deviations. The standard deviation of GRULC is 4.1 percentage points and the standard deviation of DCA is 2.8 percentage points.

Figure 2 shows the impulse responses for identification scheme a) in which there are no contemporaneous effects. The upper left plot shows the impulse response of DCA to a one standard deviation shock in DCA in period 1. The effect of the shock dies out relatively quickly but with some overshooting in the third and fourth years. The upper right plot shows the effect on DCA of a one standard deviation increase in GRULC. It follows that the effect is very subdued in both statistical and economic 
terms, and possibly with the "wrong” sign, i.e. a shock implying higher growth in relative unit labour cost has a positive effect on the change in the current account balance (an “improvement”).

The lower left plot shows the impulse response of GRULC to a shock in DCA amounting to a one standard deviation in period 1 . The result is a reduction of GRULC for two periods of approximately one percentage point in each period. The effect on GRULC accumulated over all 10 periods is -1.3 percentage points. In other words, a one percentage point increase in net capital outflows (increased capital outflow or reduced capital inflow) leads to a decrease of approximately 0.5 percent in unit labour costs over time. The magnitudes also seem to be significant in an economic sense. Finally, the lower right plot shows the impulse response of GRULC to a one standard deviation shock in GRULC.

Figure 3 presents impulse responses for each of the three identification schemes, a)-c), facilitating easy comparison across the identification schemes. To save space the autoregressive impulse responses are omitted as they resemble those shown in the upper left and lower right plots in Figure 2 in all cases. The upper panel depicts impulse responses for identification scheme a) in which there are no contemporaneous effects. These are the same impulse responses that were presented in Figure 2. 
Figure 3 Response of DCA and GRULC to innovations in GRULC and DCA, different identification schemes, $27 \mathrm{EU}$ countries
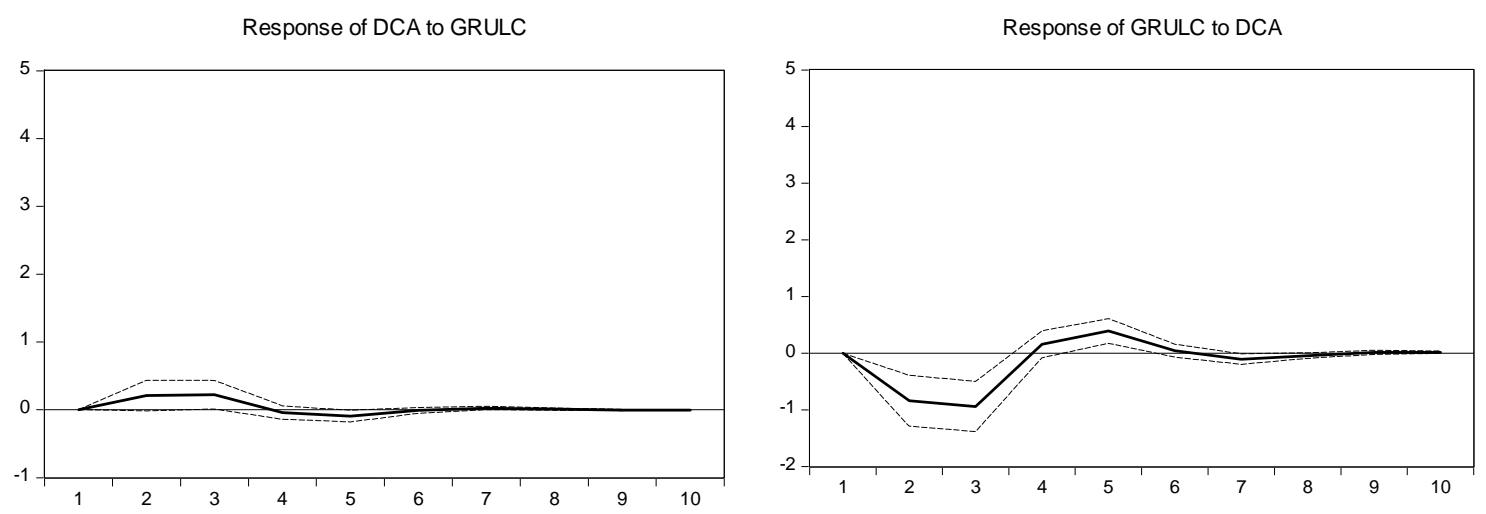

(a) Non-factorised innovations

Response of DCA to GRULC

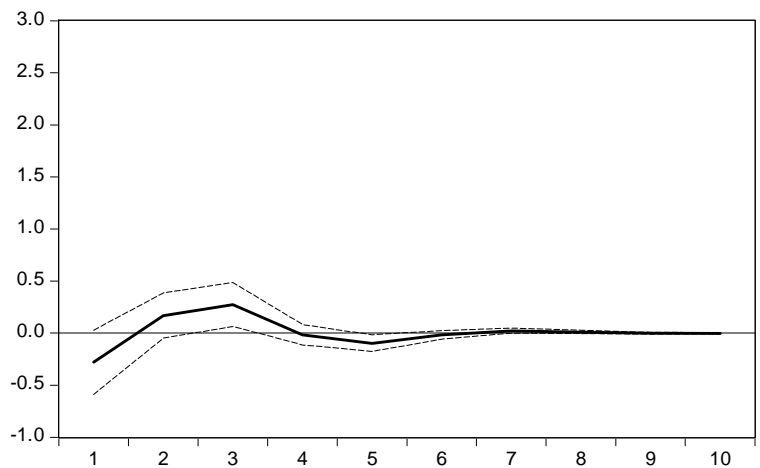

Response of GRULC to DCA

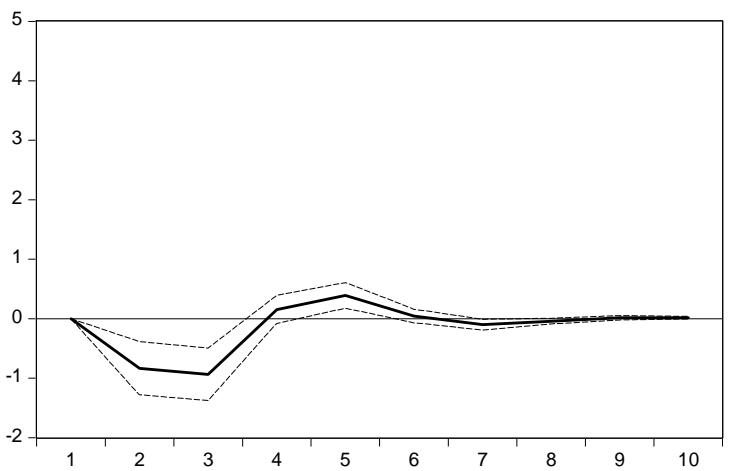

(b) Cholesky decomposition, only contemporary effects from GRULC to DCA

Response of DCA to GRULC

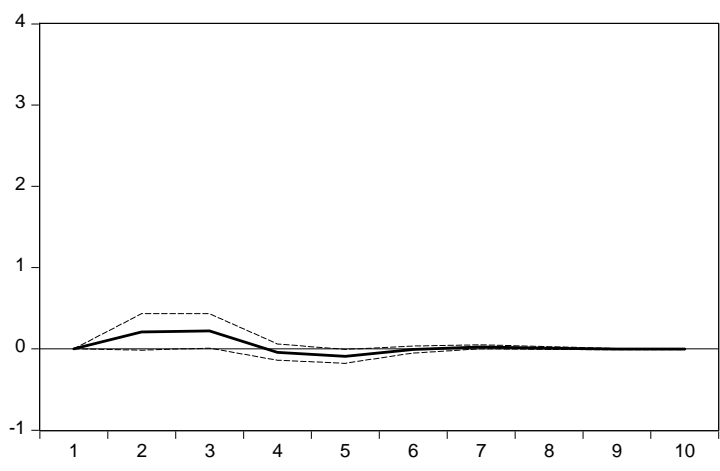

Response of GRULC to DCA

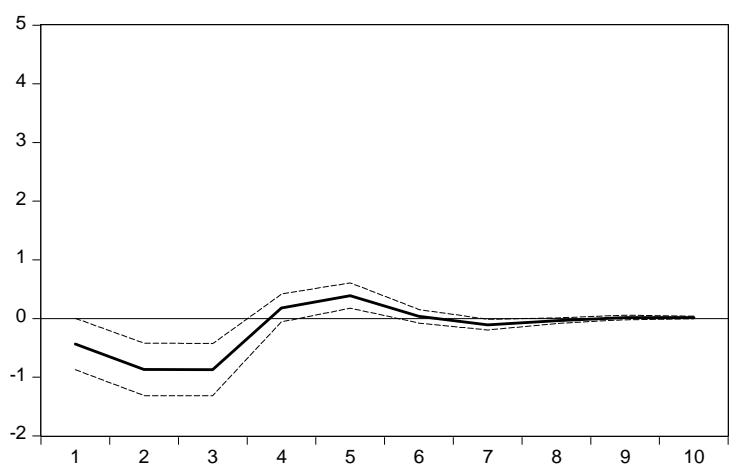

(c) Cholesky decomposition, only contemporary effects from DCA to GRULC

Note: The solid line depicts the impulse response and the dashed lines the \pm two standard deviations. The standard deviation of GRULC is 4.1 percentage points and the standard deviation of DCA is 2.8 percentage points. 
The centre panel presents the impulse responses for identification scheme b) in which GRULC can affect CA immediately, while the reverse is ruled out. The left plot depicts the response of DCA to a one standard deviation increase in GRULC in period 1. In this case the immediate response is negative, although the effect is not statistically significant at the 5 percent level, while the response is positive in periods 2 and 3 and subsequently dies out. Thus, a possible negative effect on DCA of a one-deviationincrease in GRULC is imprecisely determined and is anyway reversed already from the following period. The right plot shows the response of GRULC to a shock in DCA; the dynamics resemble the dynamics of the corresponding impulse responses in the nonorthogonalised model.

The bottom panel shows the impulse responses for identification scheme c), which assumes that DCA can affect GRULC immediately while effects in the opposite direction take place with a lag. It follows from the left plot that GRULC has little effect on DCA and the previously observed "wrong sign" also appears with this orthogonalisation. It follows from the right plot that a shock in DCA now has an immediate negative effect on GRULC, although not one that is statistically significant at the 5 percent level, and then negative effects the following two years as also observed with identification schemes a) and b).

The conclusion from the impulse responses in Figure 3 is that irrespective of the identification scheme, the main results from Section 4 also apply in the VAR model. First, changes in the relative unit labour cost generally have little effect on the current account balance. In most cases the effect appears to be positive, implying that improved competitiveness leads to larger net capital inflows, i.e. a "worsening” of the current account balance. ${ }^{13}$ The exception is identification scheme b) where GRULC can affect CA contemporaneously, but the negative effect is short-lived and not statistically significant. Second, changes in the current account balance seem to affect the relative unit labour cost. Increasing current account deficits, signifying increasing

\footnotetext{
13 The impulse responses with the "wrong" sign would be consistent with an improvement in competitiveness making the country more attractive as an investment destination and leading to capital inflows. The effect is, however, statistically insignificant in all three identification schemes.
} 
capital inflows, are followed by deteriorating competitiveness in the form of the unit labour cost increasing faster than it does in the core euro area countries.

The results obtained are robust not only to the choice of identification scheme, but also to the sample of countries, the time sample and the measure of capital flows. We will briefly discuss some of the robustness analyses we have undertaken.

Country samples. The impulse responses for the sample of EA12 countries and for the sample of CEE countries take the same shape as those for the full sample presented in Figure 2. This point is illustrated in Figure B1 in Appendix B in which the impulse responses for the CEE countries, cf. Column (4.3) in Table 4, are shown. It is noticeable that the effect of a one standard deviation DCA shock on GRULC is somewhat larger for the sample of CEE countries than for the full sample.

Time samples. We have re-estimated the VAR models in Table 4 using the time sample 1998-2007, i.e. the sample end before the outbreak of the global financial crisis. The lower number of observations reduces the precision with which the coefficients are estimated, but otherwise the changes are small. The impulse responses depict the previously observed pattern of causality (not shown). ${ }^{14}$

Measures of capital flows. We estimated a VAR model with GRULC and the current account balance CA (instead of changes in the current account balance, DCA). The impulse responses using identification schemes a)-c) are reproduced in Figure C1 in Appendix C. The results are essentially as before; changes in the relative unit labour cost have no or counter-intuitive effect on the current account balance, whereas innovations in the current account balance affect changes in the relative unit labour cost. The use of real effective exchange rate indices as measures of competitiveness also leads to impulse responses entailing the same qualitative results.

\footnotetext{
${ }^{14}$ Further reduction of the sample to include only the EA12 countries is a partial exception as the effect on GRULC of changes in DCA is slower and less pronounced than when the full sample is used.
} 


\section{Final comments}

The Euro Plus Pact adopted in March 2011 establishes monitoring by the European Commission of a number of variables presumed to predicate financial imbalances which can lead to economic disruptions or crises in individual countries. The chief concern of the Pact is the development of external price competitiveness as measured by changes in the relative unit labour cost in common currency terms. This paper discusses whether the Pact appropriately addresses the causes of financial imbalances.

The paper uses Granger causality tests and VAR models to analyse the dynamics between changes in the relative unit labour cost and the current account balance. The conclusions of the empirical analyses are robust to a number of sample and specification changes and can be summarised in two points. First, there is little or no effect from changes in the relative unit labour cost on changes in the current account balance. Second, there is a relatively strong and statistically significant link from changes in the current account balance on changes in the growth of the relative unit labour cost within a horizon of $1-3$ years.

These conclusions are consistent with a situation in which capital flows in large part depend on events outside the individual country, i.e. capital flows exhibit a substantial exogenous component. The results are thus in line with findings on other datasets, cf. Calvo et al. (1996), Kim (2000), Lipschitz et al. (2002) and Jaumotte \& Sodsriwiboon (2010). A country may experience a positive “confidence shock" and consequently become a major recipient of capital inflows. An inflow of capital leads to a nominal appreciation if the country has a floating exchange rate or it fuels a domestic boom that drives up domestic wages and prices. The net result, irrespective of exchange rate regime, is a real exchange rate appreciation or deteriorating international price competitiveness. The opposite may be a negative confidence shock that leads to a capital outflow, which over time improves competitiveness through lower wages and prices and/or a depreciating nominal exchange rate. The results are broadly consistent with findings on other dataset, cf. Saborwoski (2009) and Bakardzieva et al. (2010). 
The finding that capital flows are likely to entail changes in competitiveness while the reverse effect is subdued or non-existent suggests that current account developments may be an important indicator of future macroeconomic performance. The same conclusion is reached by Giavazzi \& Spaventa (2010) and Jaumette \& Sodsriwiboon (2010). The findings may, however, raise the question of whether the Euro Plus Pact targets the messenger of economic imbalances rather than (one of) the underlying causes. Countries subject to large capital inflows experience upward pressure on relative unit labour costs, while countries with large capital outflows will experience downward pressure on relative unit labour costs. The developments in unit labour costs are endogenous and partly determined by capital flows. This may suggest that the Euro Plus Pact may have limited ability to impact unit labour costs and even if it is possible, this may have little effect on the accumulation of current account imbalances.

The results of this paper should not be taken to imply that price competitiveness does not matter for economic performance in the longer term. The relative unit labour cost or other measures of competitiveness may still signal the emergence of "imbalances" in individual economies. The argument is instead that price competitiveness is an endogenous variable, which is determined by a whole range of factors in the individual economy and the surrounding economic environment. One such factor is international capital flows, proxied in this paper by the current account balance, and this factor seems to have substantial predictive power. This would suggest that it is important to monitor the current account balance and possibly take remedying measures in cases where developments in the current account balance are perceived to be unsustainable (Holinski et al. 2012, De Grauwe 2011).

The analysis in this paper provides clear results that are largely robust to different samples and specifications. Even so, the analysis may be substantiated or extended in a number of ways. First, additional variables could be included in the VAR model in order to model the adjustment process in more detail. A richer specification of the VAR may also be a way to investigate the underlying economic mechanisms behind the observed pattern of causality. Second, quarterly data might make it easier to establish the direction of causality and estimate the adjustment patterns for different innovations. Third, it might be possible to ascertain the causality between international 
competitiveness and capital flows using other means of identification such as instrumentation and event studies. Fourth, it could be useful to divide capital flows into different components, including foreign direct investment, portfolio investment and loans etc., as this would provide information on whether different components affect competitiveness in different ways (Bakardzhieva et al. 2010). Finally, it may be possible to undertake analyses of linkages between competitiveness and capital flows in individual countries in cases where long data series are available. 


\section{Literature}

Agenor, Pierre-Richard (1998): “Capital inflows, external shocks, and the real exchange rate”, Journal of International Money and Finance, vol. 17, no. 5, pp. 713-740.

Arellano, Manuel \& Olympia Bover (1995): “Another look at the instrumental variable estimation of error-components models”, Journal of Econometrics, vol. 68, no. 1, pp. 29-51.

Bachman, Daniel David (1992): "Why is the U. S. current account deficit so large? Evidence from vector autoregressions”, Southern Economic Journal, vol. 59, no. 2, pp. 232-240.

Bahmani-Oskooee, Mohsen \& Orhan Kara (2003): "Relative responsiveness of trade flows to a change in prices and exchange rate”, International Review of Applied Economics, vol. 17, no. 3, pp. 293-308.

Bakardzhieva, Damyana, Sami Ben Naceur \& Bassem Kamar (2010): “The impact of capital and foreign exchange flows on the competitiveness of developing countries”, IMF Working Paper, no. WP/10/154, International Monetary Fund.

Belke, Ansgar \& Christian Dreger (2011): “Current account imbalances in the euro area: catching up or competitiveness”, DIW Discussion Papers, no. 1106, Deutsches Institut for Wirtschaftsforschung.

Blundell, Richard \& Stephen Bond (1998): "Initial conditions and moment restrictions in dynamic panel data models”, Journal of Econometrics, vol. 87, no. 1, pp. 115-143.

Böhm-Bawerk, Eugen (1924). "Unsere passive Handelsbilanz” [Our passive trade balance], in: Franz X. Weiß (ed.). Gesammelte Schriften von Böhm-Bawerk, Wien und Leipzig: Hölder-Pichler-Tempsky, vol. I.

Boyd, Derick, Gugielmo Maria Caporale \& Ron Smith (2001): "Real exchange rate effects on the balance of trade: cointegration and the Marshall-Lerner condition”, International Journal of Finance \& Economics, vol. 6, no. 3, pp. 187-200.

Calvo, Guillermo A., Leonardo Leiderman \& Carmen M. Reinhart (1993): “Capital inflows and real exchange rate appreciation in Latin America”, IMF Staff Papers, vol. 40, no. 1, pp. 108-151.

Calvo, Guillermo A., Leonardo Leiderman \& Carmen M. Reinhart (1996): “Inflows of capital to developing countries in the 1990s”, The Journal of Economic Perspectives, vol. 10, no. 2, pp. 123-139.

Corden, W. Max \& J. Peter Neary (1982): "Booming sector and de-industrialisation in a small open economy”, Economic Journal, vol. 92, no. 368, pp. 825-848. 
De Grauwe, Paul (2011): “The governance of a fragile eurozone”, CEPS Working Document, no. 346, Centre for European Policy Studies.

Dullien, Sebastian \& Ulrich Fritsche (2008): "Does the dispersion of unit labor cost dynamics in the EMU imply long-run divergence?”, International Economics and Economic Policy, vol. 5, no. 3, pp. 269-295.

Edwards, Sebastian (1988): "Real and monetary determinants of real exchange rate behavior: theory and evidence from developing countries”, Journal of Development Economics, vol. 29, no. 3, pp. 311-341.

European Council (2011): “European Council - 24/25 March 2011 - Conclusions”, General Secretariat of the Council, European Council, http://www.consilium.europa.eu/uedocs/ cms_data/docs/pressdata/en/ec/120296.pdf.

Fischer, Christoph (2007): "An assessment of the trends in international price competitiveness among EMU countries”, Deutsche Bundesbank, Discussion Paper, Series 1: Economic Studies, no. $08 / 2007$.

Gabrisch, Hubert (2011): “A macroeconomist’s view on EU governance reform: why and how to establish policy coordination?”, Economic Annals, vol. LVI, no. 191, pp. 69-88.

Giavazzi, Francesco \& Luigi Spaventa (2010): "Why the current account may matter in a monetary union: lessons from the financial crisis in the euro area”, CEPR Discussion Paper, no. 8008, Centre for Economic Policy Research.

Groll, Dominik \& Bjorn van Roye (2011): "Price competitiveness divergence in the euro area: The level matters!”, Kiel Policy Brief, no. 24, Kiel Institute for the World Economy.

Gros, Daniel \& Cinzia Alcidi (2011): “Sense and nonsense of the Euro-Plus Pact”, The 2011 TGAE Report, Notre Europe, pp. 83-90.

Gros, Daniel (2011): “Competitiveness pact: flawed economics”, CEPS Commentaries, Centre for European Policy Studies, 18 March, http://www.ceps.eu/book/competitiveness-pact-flawedeconomics.

Holinski, Nils, Clemens Kool \& Joan Muysken (2012): "Persistent macroeconomic imbalances in the euro area: Causes and consequences”, Federal Reserve Bank of St. Louis Review, vol. 94, no. 1, pp. 1-20.

Isard, Peter (2007): “Equilibrium exchange rates: assessment methodologies”, IMF Working Paper, no. WP/07/296, International Monetary Fund. 
Isard, Peter, Hamid Faruqee, G. Russell Kincaid \& Martin Fetherston (2001): Methodology for Current Account and Exchange Rate Assessments, IMF Occasional Paper, no. 209, International Monetary Fund.

Jaumotte Florence \& Piyaporn Sodsriwiboon (2010): "Current account imbalances in Southern euro area”, IMF Working Paper, no. WP/10/139, International Monetary Fund.

Keynes, John M. (1929): “The German transfer problem”, Economic Journal, vol. 39, no. 153, pp. 1-7.

Keynes, John M. (1942): “Proposals for an international currency (or clearing) union”, in J. Keith Horsefield (ed.): The International Monetary Fund 1945-1965. Twenty Years of International Monetary Cooperation, vol. III: Documents, International Monetary Fund, pp. 3-19.

Kim, Yoonbai (2000): “Causes of capital flows in developing countries”, Journal of International Money and Finance, vol. 19, no. 2, pp. 235-253.

Krugman, Paul \& Maurice Obstfeld (2003): International Economics. Theory and Policy, Boston and London: Addison Wesley Publishing, 6th intl. ed.

Lartey, Emmanuel K. K. (2008): “Capital inflows, Dutch Disease effects, and monetary policy in a small open economy”, Review of International Economics, vol. 16, no. 5, pp. 971-989.

Lipschitz, Leslie, Timothy Lane \& Alex Mourmoumas (2006): “Capital flows to transition economies: master or servant?”, Finance a uver - Czech Journal of Economics and Finance, vol. 56, nos. 5-6, pp. 202-222.

Marzinotto, Benedicta (2011): "Current account imbalances: the role of competitiveness and of financial sector dynamics”, The 2011 TGAE Report, Notre Europe, pp. 91-96.

Minsky, Hyman P. (1982): Can "It” Happen Again? Essays on instability and Finance, Armonk, New York: M.E. Sharpe.

Morande, Felipe G. (1988): “Domestic currency appreciation and foreign capital inflows: What comes first? (Chile, 1977-1982)”, Journal of International Money and Finance, vol. 7, no. 4, pp. 447-466.

Obstfeld, Maurice \& Kenneth Rogoff (1995): “Exchange rate dynamics redux”, Journal of Political Economy, vol. 102, no. 3, pp. 624-660.

Ostry, Jonathan D. (1988): "The balance of trade, terms of trade, and real exchange rate: an intertemporal optimizing framework”, Staff Papers, vol. 35, no. 4, pp. 541-573. 
Perez-Caldenty, Esteban \& Matias Vernengo (2012): “The euro imbalances and financial deregulation: a Post-Keynesian interpretation of the European debt crisis”, Levy Economics Institute, Working Paper No. 702, http://www.levyinstitute.org/pubs/wp_702.pdf.

Phillips, Leigh (2011): “Klaus warns euro pact will lead to full political union”, euobserver.com, 29 March, http://euobserver.com/19/32089.

Rajapatirana, Sarath (2003): "Capital inflows and the real exchange rate: a comparative study of Asia and Latin America”, World Economy, vol. 26, no. 4, pp. 613-637.

Reinhart, Carmen \& Vincent Reinhart (2009): “Capital Flow Bonanzas: An Encompassing View of the Past and Present”, in Jeffrey Frankel \& Francesco Giavazzi (eds.): NBER International Seminar on Macroeconomics 2008. Chicago: University of Chicago Press.

Rose, Andrew K. (1991): "The role of exchange rates in a popular model of international trade: Does the 'Marshall-Lerner' condition hold?”, Journal of International Economics, vol. 30, nos. 3-4, pp. 301-316.

Saborowski, Christian (2009): "Capital inflows and the real exchange rate: can financial development cure the Dutch disease?”, IMF Working Paper, no. WP/09/20, International Monetary Fund.

Schnabl, Gunther \& Holger Zemanek (2011): “Inter-temporal savings, current account trends and asymmetric shocks in a heterogeneous European Monetary Union”, Intereconomics, vol. 46, no. 3, pp. 153-160.

Stockhammer, Engelbert (2011): “Peripheral Europe’s debt and German wages: the role of wage policy in the euro area”, International Journal of Public Policy, vol. 7, no. 1, pp. 83-96.

Sy, Mouhamadou \& Hamidreza Tabarraei (2009): “Capital inflows and exchange rate in LDCs:

The Dutch disease problem revisited”, Paris School of Economics, Working Paper, no. 26.

The Economist (2011): “The divisiveness pact”, The Economist, 10 March.

Williamson, John (1985): The Exchange Rate System, Institute for International Economics.

Williamson, John (1994): Estimating equilibrium exchange rates. Institute for International Economics.

Wyplosz, Charles (2011): “Why Angela Merkel’s competitiveness pact is a bad idea, and what else she should do", Eurointelligence, 30 March, http://www.eurointelligence.com/.

Zemanek, Holger, Ansgar Belke \& Gunther Schnabl (2009): "Current account imbalances and structural adjustment in the euro area: how to rebalance competitiveness”, CESifo Working Paper Series, no. 2639. 


\section{Appendix A: Additional Granger causality tests}

Table A1 Panel data Granger causality tests. Dependent variable CA

\begin{tabular}{|c|c|c|c|c|c|c|}
\hline & (A1.1) & (A1.2) & (A1.3) & (A1.4) & (A1.5) & (A1.6) \\
\hline CA(-1) & $\begin{array}{c}0.614 \\
(0.054)\end{array}$ & $\begin{array}{c}0.880 \\
(0.033)\end{array}$ & $\begin{array}{c}0.709 \\
(0.046)\end{array}$ & $\begin{array}{c}0.808 \\
(0.061)\end{array}$ & $\begin{array}{c}0.772 \\
(0.150)\end{array}$ & $\begin{array}{c}0.780 \\
(0.094)\end{array}$ \\
\hline CA(-2) & .. & .. & .. & $\begin{array}{c}-0.321 \\
(0.062)\end{array}$ & $\begin{array}{c}-0.050 \\
(0.149)\end{array}$ & $\begin{array}{c}-0.432 \\
(0.035)\end{array}$ \\
\hline GRULC(-1) & $\begin{array}{c}-0.000 \\
(0.031)\end{array}$ & $\begin{array}{c}0.024 \\
(0.031)\end{array}$ & $\begin{array}{c}0.023 \\
(0.037)\end{array}$ & $\begin{array}{c}0.018 \\
(0.025)\end{array}$ & $\begin{array}{c}-0.071 \\
(0.081)\end{array}$ & $\begin{array}{c}-0.008 \\
(0.030)\end{array}$ \\
\hline GRULC(-2) & .. & .. & .. & $\begin{array}{c}0.033 \\
(0.030)\end{array}$ & $\begin{array}{c}0.001 \\
(0.054)\end{array}$ & $\begin{array}{c}0.039 \\
(0.037)\end{array}$ \\
\hline Granger causality $^{\mathrm{a}}$ & $\begin{array}{c}0.00 \\
{[0.993]}\end{array}$ & $\begin{array}{c}0.57 \\
{[0.449]}\end{array}$ & $\begin{array}{c}0.40 \\
{[0.527]}\end{array}$ & $\begin{array}{c}0.69 \\
{[0.508]}\end{array}$ & $\begin{array}{c}0.39 \\
{[0.686]}\end{array}$ & $\begin{array}{c}0.07 \\
{[0.804]}\end{array}$ \\
\hline Time sample & $\begin{array}{c}1997- \\
2011\end{array}$ & 1997-2011 & 1998-2011 & 1998-2011 & 1998-2011 & 1998-2011 \\
\hline Countries & EU27 & EU27 & EU27 & EU27 & EA12 & CEE \\
\hline Observations & 381 & 381 & 381 & 356 & 163 & 128 \\
\hline Estimation & $\mathrm{FE}$ & OLS & System GMM & $\mathrm{FE}$ & $\mathrm{FE}$ & $\mathrm{FE}$ \\
\hline
\end{tabular}

a The null hypothesis of the Granger causality test is that the lagged value(s) of the independent explanatory variable do(es) not Granger cause the dependent variable. The test statistic is F-distributed except in the case of the System GMM estimation in which it is $\chi^{2}$-distributed; the values in square brackets are $p$-values.

Notes: Standard errors are clustered along the cross section and are shown in round brackets. A constant term is included in all estimations but not shown. 
Table A2 Panel data Granger causality tests. Dependent variable GRULC

\begin{tabular}{|c|c|c|c|c|c|c|}
\hline & (A2.1) & (A2.2) & (A2.3) & (A2.4) & (A2.5) & (A2.6) \\
\hline CA(-1) & $\begin{array}{c}-0.236 \\
(0.084)\end{array}$ & $\begin{array}{c}-0.154 \\
(0.041)\end{array}$ & $\begin{array}{c}-0.208 \\
(0.124)\end{array}$ & $\begin{array}{c}-0.471 \\
(0.112)\end{array}$ & $\begin{array}{c}-0.175 \\
(0.118)\end{array}$ & $\begin{array}{c}-0.671 \\
(0.121)\end{array}$ \\
\hline CA(-2) &.. & .. & .. & $\begin{array}{c}0.202 \\
(0.101)\end{array}$ & $\begin{array}{c}0.198 \\
(0.137)\end{array}$ & $\begin{array}{c}0.136 \\
(0.113)\end{array}$ \\
\hline GRULC(-1) & $\begin{array}{c}0.067 \\
(0.055)\end{array}$ & $\begin{array}{c}0.094 \\
(0.029)\end{array}$ & $\begin{array}{c}0.131 \\
(0.068)\end{array}$ & $\begin{array}{c}0.691 \\
(0.048)\end{array}$ & $\begin{array}{c}0.267 \\
(0.098)\end{array}$ & $\begin{array}{c}0.014 \\
(0.055)\end{array}$ \\
\hline GRULC(-2) & .. & .. & .. & $\begin{array}{c}-0.142 \\
(0.046)\end{array}$ & $\begin{array}{c}-0.087 \\
(0.061)\end{array}$ & $\begin{array}{c}-0.171 \\
(0.062)\end{array}$ \\
\hline $\begin{array}{l}\text { Granger } \\
\text { causality }^{\text {a }}\end{array}$ & $\begin{array}{c}7.94 \\
{[0.009]}\end{array}$ & $\begin{array}{l}14.46 \\
{[0.000]}\end{array}$ & $\begin{array}{c}2.82 \\
{[0.093]}\end{array}$ & $\begin{array}{c}9.41 \\
{[0.001]}\end{array}$ & $\begin{array}{c}1.15 \\
{[0.353]}\end{array}$ & $\begin{array}{l}17.37 \\
{[0.001]}\end{array}$ \\
\hline Time sample & 1997-2011 & 1997-2011 & 1998-2011 & 1998-2011 & 1998-2011 & 1998-2011 \\
\hline Countries & EU27 & EU27 & EU27 & EU27 & EA12 & CEE \\
\hline Observations & 381 & 381 & 381 & 356 & 163 & 128 \\
\hline Estimation & FE & OLS & System GMM & FE & $\mathrm{FE}$ & $\mathrm{FE}$ \\
\hline
\end{tabular}

a The null hypothesis of the Granger causality test is that the lagged value(s) of the independent explanatory variable do(es) not Granger cause the dependent variable. The test statistic is F-distributed except in the case of the System GMM estimation in which it is $\chi^{2}$-distributed; the values in square brackets are $p$-values.

Notes: Standard errors are clustered along the cross section and are shown in round brackets. A constant term is included in all estimations but not shown. 


\section{Appendix B: Impulse responses for VAR model with CEE countries}

Figure B1 Response of DCA and GRULC to innovations in GRULC and DCA, different identification schemes, CEE countries

Response of DCA to GRULC

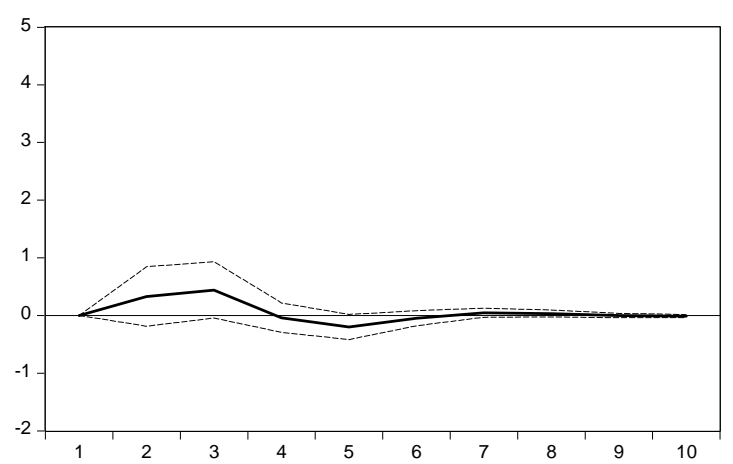

Response of GRULC to DCA

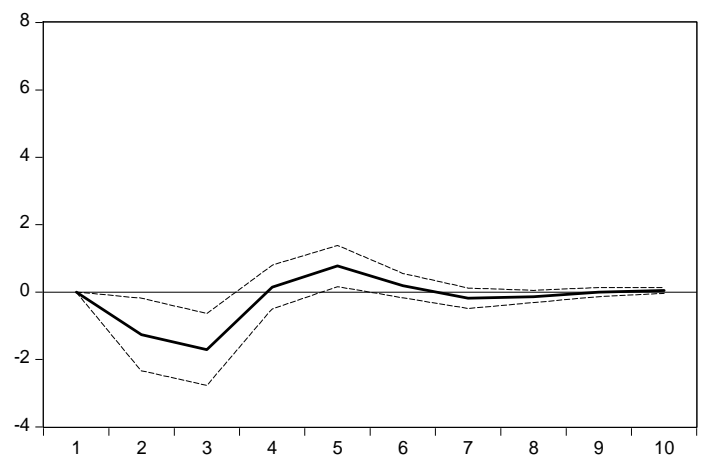

(a) Non-factorised innovations

Response of DCA to GRULC

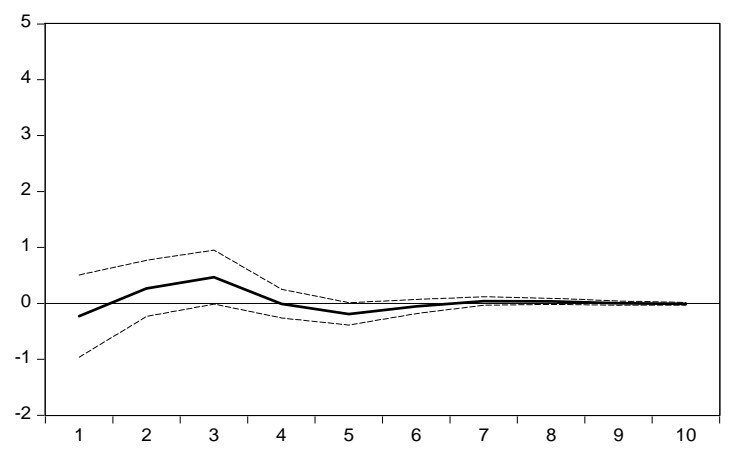

Response of GRULC to DCA

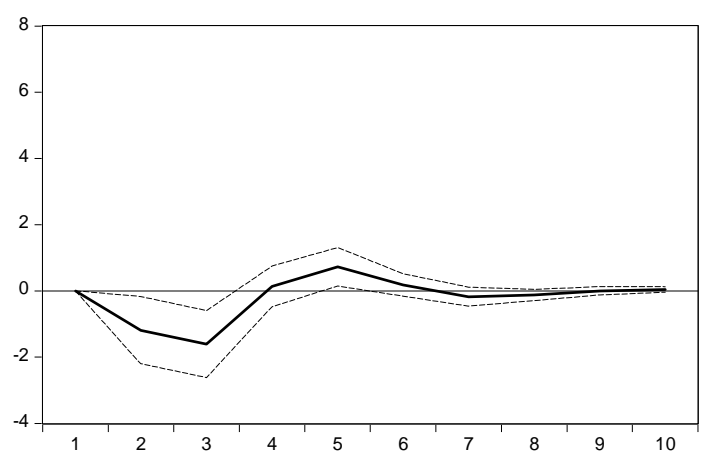

(b) Cholesky decomposition, only contemporaneous effects from GRULC to DCA

Response of DCA to GRULC

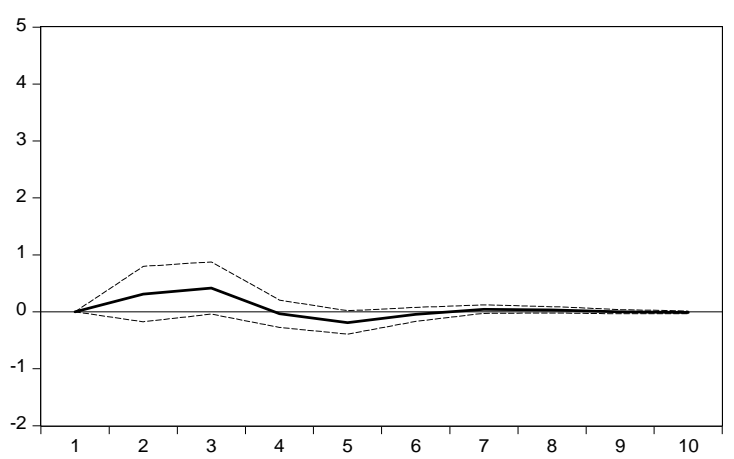

Response of GRULC to DCA

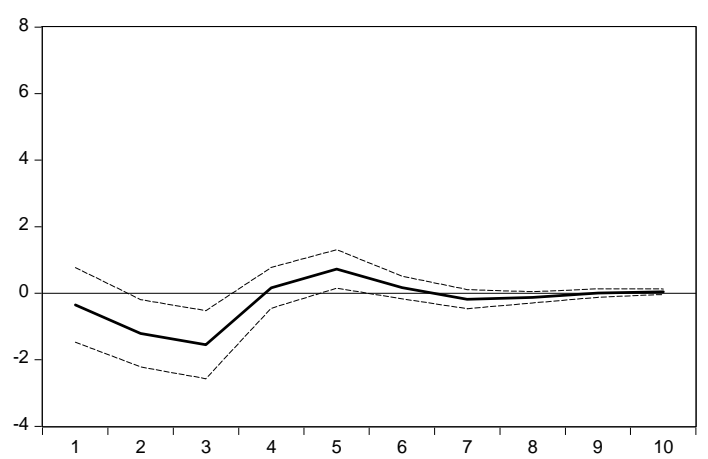

(c) Cholesky decomposition, only contemporaneous effects from DCA to GRULC

Notes: The solid line depicts the impulse response and the dashed lines the \pm two standard deviations. The standard deviation of GRULC is 6.0 percentage points and the standard deviation of DCA is 3.9 percentage points. 


\section{Appendix C: Impulse responses for VAR model with CA variable}

Figure C1 Response of CA and GRULC to innovations in GRULC and CA, different identification schemes, all countries

Response of CA to GRULC

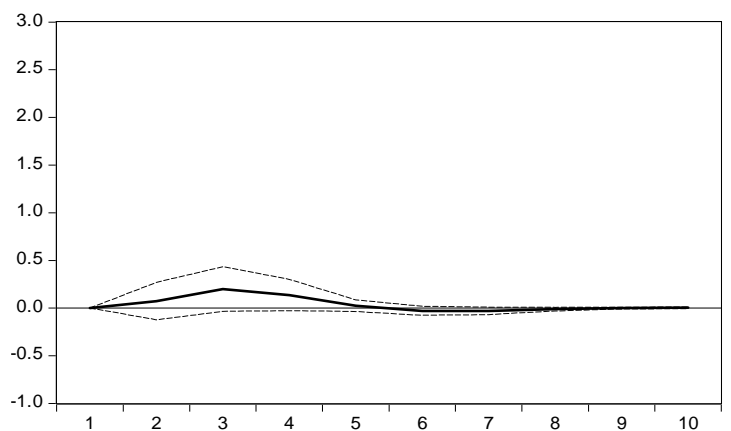

Response of GRULC to CA

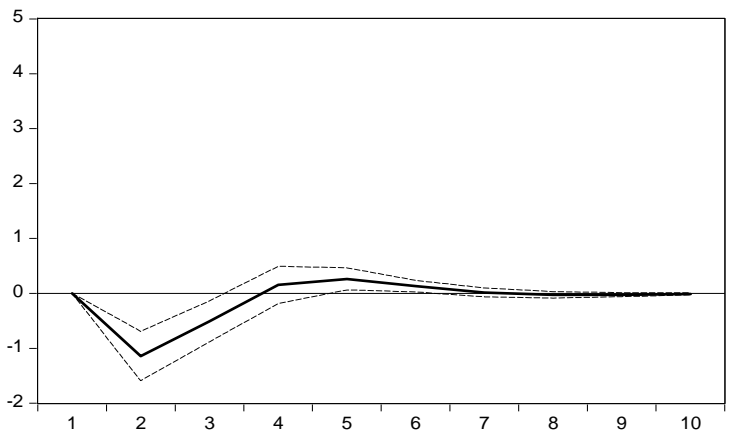

(a) Non-factorised innovations

Response of CA to GRULC

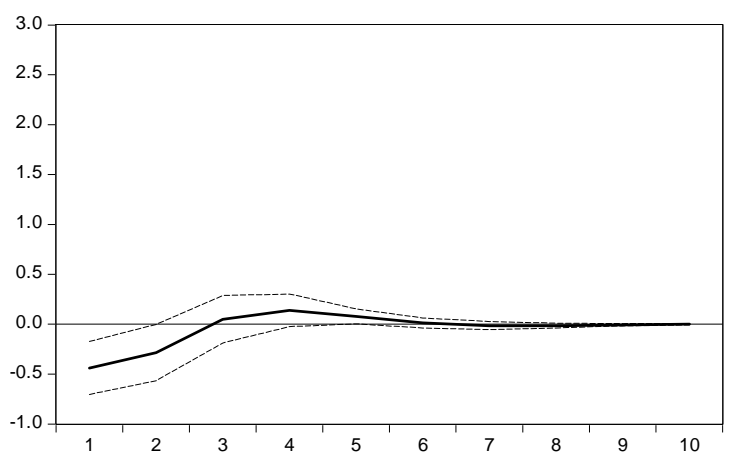

Response of GRULC to CA

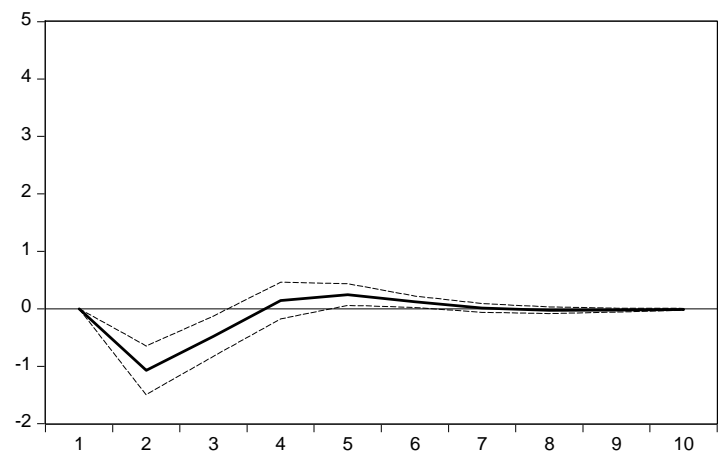

(b) Cholesky decomposition, only contemporaneous effects from GRULC to DCA

Response of CA to GRULC

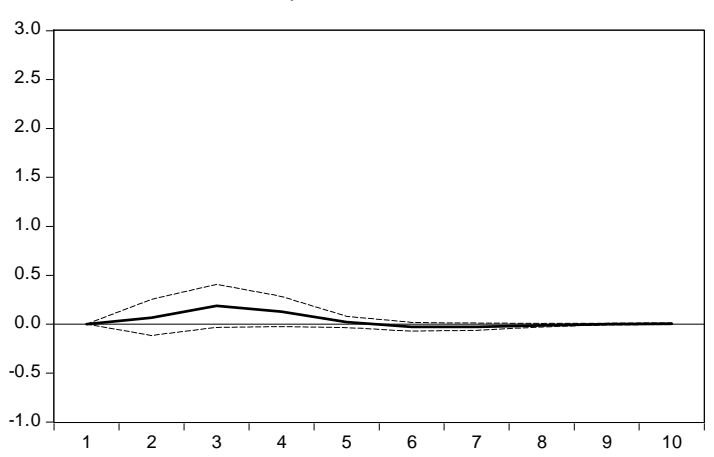

Response of GRULC to CA

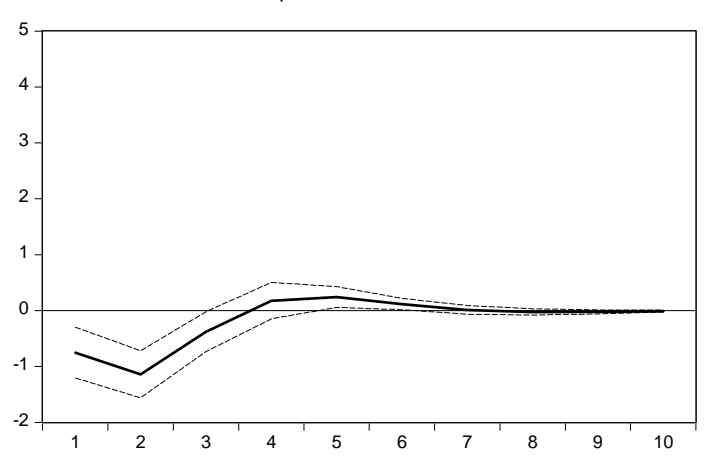

(c) Cholesky decomposition, only contemporaneous effects from CA to GRULC

Notes: The solid line depicts the impulse response and the dashed lines the \pm two standard deviations. The standard deviation of GRULC is 6.0 percentage points and the standard deviation of CA is 2.4 percentage points. 